\title{
To Trade or Not to Trade: The Strategic Trading of Insiders around News Announcements
}

\author{
Adriana Korczak \\ Piotr Korczak \\ Meziane Lasfer
}

Discussion Paper No. 09/613

October 2009

Department of Economics

University of Bristol

8 Woodland Road

Bristol BS8 1TN 


\title{
To Trade or Not to Trade: \\ The Strategic Trading of Insiders around News Announcements
}

\author{
Adriana Korczak, Piotr Korczak and Meziane Lasfer ${ }^{*}$
}

31 October 2009

\begin{abstract}
We argue that insiders' decisions to trade in short windows before news announcements are likely to result from a trade-off between the incentives to capitalize on the foreknowledge of the disclosure and the risk of regulatory scrutiny and lost reputation. We provide evidence that insider buying is driven by the trade-off, while selling is primarily influenced by the deterring effect of the regulatory and reputation risks. We show that insiders strategically choose the amount of shares bought ahead of good news announcements. They increase their purchases as the price impact of the news goes up, but we find that the amount of shares purchased levels off as the news becomes extreme. In contrast, we find that the probability of insider selling significantly decreases with the price impact of the forthcoming bad news. To further support our arguments on the importance of incentives and disincentives to trade, we show that the strategic trading is mainly observed in the most price-sensitive groups of news announcements, it is clearly pronounced for best informed executives (CEOs), and that trading patterns change with changes in regulations, and insiders with higher reputation at risk limit their trading ahead of bad news.
\end{abstract}

\section{JEL Classification: G14, G18, K22}

Keywords: insider trading, private information, information disclosure, regulation

\footnotetext{
* The first and second author are from the School of Economics, Finance and Management, University of Bristol. The third author is from Cass Business School, City University London. The anonymous referee, Martin Walker (the editor of JBFA), Doug Pederson, Peter Szilagyi, and participants at the 2009 JBFA Capital Markets Conference, the 2007 EFMA Annual Meeting, the 2008 FMA Annual Meeting, and the 2008 FMA European Conference, as well as seminar participants at the University of Bristol, the University of Salamanca and the CFA Society provided very helpful suggestions and comments on earlier drafts of the paper. The authors would like to thank Neslihan Ozkan for sharing her compensation and board structure data with them, and Dmitry Kokhanov for excellent research assistance. The authors remain responsible for any remaining errors.
}

Address for correspondence: Piotr Korczak, School of Economics, Finance and Management, University of Bristol, 8 Woodland Road, Bristol BS8 1TN, United Kingdom, email: P.Korczak@bristol.ac.uk. 


\section{To Trade or Not to Trade:}

\section{The Strategic Trading of Insiders around News Announcements}

\section{Introduction}

Studies on the association between stock trading by corporate insiders and subsequent significant corporate events emerged as soon as excess returns earned by insiders were confirmed in seminal papers by Jaffe (1974), Finnerty (1976) and Seyhun (1986), among others. A widely accepted explanation for insiders' abnormal profits was the superior knowledge about their firms' prospects and the use of this foreknowledge in trading decisions. Later alternative explanations focused on insiders' ability to recognize pricing errors made by outside investors and trading against the market sentiment. While many studies provide evidence consistent with the latter arguments and document the contrarian trading attitude of insiders (e.g., Seyhun, 1992a; Rozeff and Zaman, 1998; Jenter, 2005), the question on the link between insider trading and subsequent corporate events and news announcements remains still unanswered In particular, how insiders' motives and incentives shape their trading choices shortly before corporate news announcements? Is the decision to trade on the foreknowledge of corporate news the result of a trade-off between benefits and costs of trading? Is the probability and the amount of buying (selling) shortly before positive (negative) news announcements non-linearly related to the information content of the news disclosure? Is the propensity to trade dependent on the board characteristics and the position of the insider within the firm? How effective is the change in regulations in mitigating the trading propensity of insiders on private information? We construct a unique database of 119,179 news announcements made by U.K. companies, and 8,086 insider trading events over the period 1999-2002, to answer these questions.

Our main findings can be summarized as follows. We find that insider trading is more prevalent before good than before bad news announcements, and insiders refrain from trading 
in the blackout periods before earnings disclosures. The magnitude of insider buying before good news increases as the information content of the news goes up, suggesting that insiders use their foreknowledge to trade profitably. However, as the market reaction to the news becomes very large, the potential risks of regulatory scrutiny and lost reputation increase, and the insiders' propensity to trade on the information starts to smooth out. We further uncover that in their trading decisions before bad news, insiders strategically choose whether to sell rather than how much to sell, and the probability of insider selling significantly decreases with the importance of the forthcoming news. We argue that insiders' decision to sell on private information is strongly affected by the regulatory risk and hence they want to avoid any suspicion and decide not to trade at all when the forthcoming news is significant. For both good and bad news, we find that the results on strategic trading are driven by news in, on average, the most price-sensitive categories of announcements. Since it is generally accepted that such announcements attract close attention of regulators and media, the finding provides further evidence that the regulatory and reputational risks have a significant impact on insider trading behavior.

To further support the arguments on the incentives and disincentives to trade, we provide evidence on clearly pronounced strategic informed trading by CEOs, who have the best access to information in the firm, while for the case of the chairman the trading propensity on insider information is relatively weak. We relate these results to the characteristics of the UK corporate governance code, which stipulates that the roles of the chairman and CEO should be split, and the chairman is usually a non-executive director, who is unlikely to have more information than the CEO. Interestingly, we find that the firm's corporate governance characteristics do not affect the trading propensity. Finally, we find some evidence that insider trading patterns change when the regulatory regime becomes stricter, and that insiders with higher reputation at risk limit their trading ahead of bad news, 
consistent with the arguments on the perceived legal and reputational costs of trading. Our main findings are also robust to alternative measures of the price impact of the news that allow for potential information leakage ahead of announcement and preemption of the information content of news by insider trading.

Our study contributes to the stream of insider trading literature which investigates the importance of the decision to trade versus not to trade (e.g., Piotroski and Roulstone, 2005, 2008; Huddart et al., 2007; Roulstone, 2008; Kallunki et al., 2009). The novelty of our approach lies in the focus on insider trading decisions ahead of all corporate news announcements as opposed to other studies that analyze earnings announcement only. This allows us to better explore insiders' incentives and disincentives to trade and the cost-benefit trade-off. Insider trading regulations include an explicit ban on trading by corporate insiders in the run-up to earnings announcements in the U.K. and in some other jurisdictions. In countries in which the bans related to earnings announcements are not introduced at the country level, like, for example, in the U.S., the majority of firms include them in their firmlevel insider trading policies (Bettis et al., 2000). In either case, trading shortly before an earnings announcement is a clear violation of the rules and can be expected to cause an immediate disciplinary action. In this respect, the concept of the strategic decision to trade or not to trade driven by incentives and disincentives is of little practical meaning, and a test would be to a large extent limited to the question on the effectiveness and enforcement of the rules. On the other hand, a broad set of corporate news announcements creates a good testing ground. In line with common international practices, U.K. regulations prohibit trading by insiders when they are in possession of any information which may constitute inside information. However, in practice, inside information is difficult to define. One of the features of inside information is a significant effect on the stock price it would have if publically available, but it is left to the assessment by an individual what a significant impact is. It is 
acknowledged that there is no percentage figure that can be set to clearly indicate a significant effect (see, Disclosure Rules, FSA Handbook, July 2006, p. 17). As noted by Friederich et al. (2002), this creates a large grey area open to interpretation. Hence, we observe a large set of specific news directly related to the firm and originating from inside the firm to which one can expect corporate insiders to be privy, and for which the insiders have to take a view on their price significance. This leads to the importance of individual assessment and interpretation, and put together with the incentives to profit from the foreknowledge of the announcement, sets the ground for our tests.

The findings of this paper can be of interest to stock market practitioners. Corporate insiders not only play a key role in the creation of shareholder wealth, but also play an important informational role in securities markets. A large body of earlier insider trading literature documents that insiders outperform the market in their trades, and in this paper we shed more light on how insiders make their stock trading decisions when they are thought to be in possession of private information. The analysis of insiders' motives, incentives and disincentives can help understand how insider trading can lead to incorporation of private information into stock prices. Even though we do not provide direct tests of regulations as we focus only on insider trading decisions with the regulatory framework as one of the factors, we expect our results to provide information for policymakers and market regulators who design and enforce insider trading laws.

The remainder of the paper is organized as follows. Section 2 provides a primer on U.K. insider trading regulations, Section 3 introduces the literature background and develops our hypothesis, and Section 4 introduces the data and methodology. Section 5 presents the main empirical findings and Section 6 provides further tests and robustness checks. Section 7 concludes the paper. 


\section{U.K. Insider Trading Regulations}

Trading by corporate insiders is regulated in the United Kingdom by government legislation and non-statutory codes of practice (see, e.g., Hillier and Marshall, 1998; Fidrmuc et al., 2006). Insider trading has been a criminal offence in the U.K. since the introduction of the Companies Act 1980, and the Criminal Justice Act 1993 sets out the current definition of insider dealing. According to this Act, if an individual has inside information through being an insider (e.g., a director, employee or shareholder), he must not deal in securities that are price-affected by that information. Inside information is defined as information that is related to particular securities or a particular issuer, is specific and precise, has not been made public, and, if made public, is likely to have a significant effect on the price of the securities. The Disclosure Rules published by the Financial Services Authority (FSA) acknowledge though that there is no percentage figure that can be set to clearly indicate a significant effect, and this will vary from company to company (see, Disclosure Rules, FSA Handbook, July 2006, p. 17). According to the Criminal Justice Act 1993, an individual found guilty of insider trading is liable to a fine or imprisonment. The regulations of the Criminal Justice Act 1993 were supplemented by the Financial Services and Markets Act 2000 (effective from December 1, 2001), which introduced civil penalties, such as fines or public censure, for market abuse, in addition to the penalties based on criminal prosecution, and delegated insider trading laws enforcement power to the FSA. In 2001 the FSA implemented the Code of Market Conduct as a standard setting document which gives a thorough guidance on the behavior that can be considered market abuse.

The first U.K. prosecution under the insider trading laws took place in 1981 (Bhattacharya and Daouk, 2002). However, the enforcement of the rules remained weak and between 1981 and 1998, there were only 17 prosecutions, 12 of which were successful, 
compared with 57 cases brought in the U.S. in 1997 alone. ${ }^{1}$ It is acknowledged that it was extremely difficult to prosecute insider trading cases under the criminal law. ${ }^{2}$ The first civil penalty in the new regime after the enactment of the Financial Services and Markets Act 2000 was imposed by the FSA in February 2004.

Detailed guidelines on share dealings by corporate insiders are also contained in the Model Code, currently part of the Listing Rules issued by the FSA, and first introduced by the London Stock Exchange in 1977. The Model Code is a non-statutory code of good practice and it imposes restrictions beyond those imposed by law. Its guidelines are aimed to ensure that insiders in their trading decisions 'do not abuse, and do not place themselves under suspicion of abusing, inside information that they may be thought to have' (Listing Rules, FSA Handbook, July 2006, p. 131). According to the Model Code, insiders are banned from trading in 'prohibited periods', which include 'close periods' associated with earnings announcement, and any periods when there is 'any matter which constitutes inside information in relation to the company' (Listing Rules, FSA Handbook, July 2006, p. 132). A 'close period' covers 60 days before the preliminary announcement of annual or half-yearly results, or 30 days before quarterly results, depending on the reporting frequency. Any individual who is identified by law as an insider must not trade in any securities of the company without having permission to trade ('clearance to deal') from a chairman or a director designated in the company for this purpose. The clearance is not given during 'prohibited periods' except for a permission to sell when an insider does not possess any inside information and has 'a pressing financial commitment that cannot be satisfied otherwise than by selling the relevant securities of the company' (Listing Rules, FSA Handbook, July 2006, p. 134).

\footnotetext{
${ }^{1}$ See, the speech by Thomas C. Newkirk and Melissa A. Robertson from the U.S. Securities and Exchange Commission, delivered on September 19, 1998, available at: http://www.sec.gov/news/speech/speecharchive/1998/spch221.htm

${ }^{2}$ See, the speech by Margaret Cole, Director of Enforcement at FSA, delivered on March 17, 2007, available at: http://www.fsa.gov.uk/pages/Library/Communication/Speeches/2007/0317_mc.shtml
} 
The Companies Act 1985 and the disclosure standards of the London Stock Exchange (replaced later by the FSA's Disclosure Rules) outline the obligations to report stock transactions by corporate insiders. Insiders must report their trades to the company no later than the fifth business day after the transaction, the company notifies the London Stock Exchange (LSE) about the transaction no later that the following business day, and the information is then disseminated immediately. In practice, in the vast majority of cases, this process takes only one day. For example, Fidrmuc et al. (2006) find that for $85 \%$ of trades in their sample the announcement date coincides with the trading date or the following date.

\section{Literature Background and Hypothesis}

A number of studies analyze the informational role of insider transactions and a related question on the need to regulate trading on inside information. Generally, previous research finds that corporate insiders outperform the market in their trading and the announcements of transactions by insiders reveal information that triggers significant stock price reactions. ${ }^{3}$ The results indicate that financial markets do not compound private information and that there is a wealth transfer from uninformed investors to individuals with privileged information. Insiders' gains and the contending motives for insider trading have resulted in controversies as to whether insider trading should be encouraged or regulated. Some studies argue that the rules against insider trading prevent prices from reflecting the correct value of the firm and, thus, damage market efficiency. It is argued that with insider trading, market efficiency increases as prices are likely to reflect both publicly and privately held information (Manne, 1966; Carlton and Fischel, 1983). In that case, insider trading should be permitted and insiders will trade freely to capitalize on private information without incurring any risk of regulatory scrutiny. Other studies suggest, however, that if insiders are

\footnotetext{
${ }^{3}$ See, e.g., Jaffe (1974), Finnerty (1976) and Seyhun (1986) for earlier evidence on the U.S. market, Ravina and Sapienza (2009) for latest findings on the U.S., and Pope et al. (1990), Gregory et al. (1997), Friederich et al. (2002) and Fidrmuc et al. (2006) for U.K. evidence.
} 
allowed to trade freely, non-informed investors become aware of the wealth transfer induced by insider trading and will refrain from trading (Ausubel, 1990; Fishman and Hagerty, 1992). Such attitude will lead to inefficiency and illiquidity. Despite the inconclusive debate among law and economics scholars, in practice, laws regulating insider trading are relatively common across the vast majority of countries although their level of enforcement differs from one country to another (Bhattacharya and Daouk, 2002). The regulators around the world have a widespread aim to prohibit trading in securities using material non-public information in order to promote fairness of the market and to prevent insiders from abusing their privileged position.

The empirical evidence on how insiders trade when they are in possession of private information reveals that they trade several months or even years before significant corporate events are announced. These events include takeover bids (Seyhun, 1990), seasoned equity offerings (Karpoff and Lee, 1991), stock repurchases (Lee et al., 1992), bankruptcies (Seyhun and Bradley, 1997), earnings downturns (Ke et al., 2003), and accounting scandals (Agrawal and Cooper, 2008). However, insiders' propensity to trade is reduced as the event approaches. For example, Ke et al. (2003) find little abnormal insider selling in two quarters immediately prior to the earnings downturn, and Huddart et al. (2007) and Kallunki et al. (2009) find that insiders refrain from trading profitably in short windows before earnings announcements. Similarly, Piotroski and Roulstone (2005) find that the probability of insider selling is driven by next year's decreases in firm's profitability, and is unrelated to the current year's changes in performance. Furthermore, little association is found between insider trading and the subsequent management earnings forecasts (Noe, 1999), the content of earnings announcements (Sivakumar and Waymire, 1994), and a wide range of non-earnings announcements, including dividends news and operational plans (Givoly and Palmon, 1985). The decrease in the propensity of insiders to trade on private information just before corporate 
events can be explained by the increased risks of the regulatory scrutiny and litigation, as well as potential political and reputational costs (e.g., Agrawal and Cooper, 2008; Piotroski and Roulstone, 2008). The deterring role of regulations is supported by the fact that insider trading patterns are found to change with changes in the securities law (e.g., Garfinkel, 1997; Piotroski and Roulstone, 2005). Still, some studies find a strong relationship between insider trading and the information content of the proximate earnings releases (Lustgarten and Mande, 1995) and uncover that insiders profit from superior knowledge about proximate filings of Forms 10-K and 10-Q that contain detailed financial results (Huddart et al., 2007).

Piotroski and Roulstone (2008) shed more light on the incentives to capitalize on private information and disincentives created by legal and reputational risks in their analysis of the non-linear link between insider trading and next year's earnings innovation. They find that the likelihood of trading increases with the magnitude of earnings innovation, but it is attenuated in the case of extreme news, consistent with the trade-off argument on the benefits and costs of trading on private information. In a related study, Roulstone (2008) finds further evidence on the non-linear link between insider trading and earnings information for quarterly earnings announcements.

In this paper we extend the approach in Piotroski and Roulstone (2008) and Roulstone (2008) and analyze how insiders make their trading decisions just before a broad set of corporate announcements. As outlined in Section 2, in the U.K. there is an explicit ban on trading by corporate insiders before earnings announcements. Therefore, looking at earnings only would tell us little about incentives and disincentives and would be limited to a test of the effectiveness of the regulations. On the other hand, an analysis of a large sample of diverse corporate announcements allows us to study how insiders make decisions when they have discretion on whether to trade or not. Even though regulations prohibit trading on pricesensitive private information, given the difficulties in defining unambiguously what 
constitutes price-sensitive information, and the difficulties in enforcement of the insider trading rules, insiders are likely to weigh the benefits of capitalizing on their foreknowledge of the disclosure and the likelihood of attracting regulatory scrutiny and adverse attention. We also look at shorter trading windows closer to the announcement. While Piotroski and Roulstone (2008) and Roulstone (2008) analyze trading occurring over a year and over a quarter, respectively, before the news hit the market, we look at one calendar month preceding the announcement. This allows us to strengthen further the trade-off considerations. The regulatory and reputation risk when trading immediately before the news is inevitably larger as the link between private information and trading is easier for regulators to prove. Moreover, in the case of earnings, insiders are able to foresee the development of the firm's profitability and can manage the timing of their trades, and trade even several quarters ahead of the disclosure, as documented by Ke et al. (2003). In contrast, the information advantage associated with many other types of corporate announcement is short-lived. The information becomes public shortly after it is known to the firm's insiders and, hence, they have a short window of opportunity to profit from their foreknowledge.

We, therefore, explore in this paper the impact of incentives and disincentives on the decision to trade shortly before corporate news announcements. We assume that insiders know the information content of the upcoming disclosure and can predict how the market will react on the announcement date. On the one hand, we consider insiders' incentives to use their foreknowledge of the forthcoming disclosure to increase their profits by buying ahead of good news or to limit their losses by selling ahead of bad news. In the extreme, an insider can buy (sell) immediately before the news release and sell (buy) directly afterwards. In that case, the news cumulative abnormal return (CAR) can be used as a proxy for the total abnormal profits 
made on the trade, before transaction costs. ${ }^{4}$ However, the news CAR can also be interpreted as an additional profit made from trading that an insider would foregone if the trading was delayed until after the news release. If the market reaction is small, the potential gains are low, and, therefore, there is little incentive to trade. One can argue that, potentially, by trading even on information with small information content, insiders can make considerable profits if they trade large amounts. However, large volume one-directional trading can create a substantial price pressure, and the price impact of the trade can eliminate possible profits from the foreknowledge. The increasing information content of the news increases potential gains that can be made on the trade and, hence, will increase the propensity to trade.

On the other hand, the regulation is expected to hinder insiders' propensity to trade before price-sensitive information, and when the abnormal returns are high (i.e., the information is highly price-sensitive), the probability of scrutiny by the regulator increases, reducing the incentives to trade. This may also bring political costs, reputation damage and deteriorated future career prospects when insiders' activities receive adverse media and investor attention. Thus, trading will occur when the optimal cost-benefit trade-off is reached. Therefore we expect the probability and the amount of trading to be non-linearly related to the level of the information content of the news as reflected in the market reaction on the news announcement. Furthermore, as noted by Cheng and Lo (2006), the risk of litigation after selling before price decreases and buying before price increases is asymmetric. When insiders sell on bad news and the stock price drops, outside investors suffer real losses, and hence the risk of a legal action is larger. Insider buying before good news results in outsiders' opportunity losses only. Thus, insiders may be more deliberate when selling on forthcoming bad news than when buying on proximate good news. Alternatively, if insiders do not trade strategically on private information and trade, instead, for liquidity reasons only, the trades

\footnotetext{
${ }^{4}$ In the U.K. there is no short swing profit rule and insider trading in and out of the stock is permitted unlike in the U.S., where the Rule 16(b) of the Securities and Exchange Act of 1934 requires insiders to surrender any profit made on transactions that are offset within six months.
} 
will be randomly distributed and not necessarily undertaken around news announcements or related to the information content of the news.

Our predictions are related to the implications of the theoretical model in Seyhun (1992b). He shows that an increase in the value of private information leads to more insider trading, and an increase in sanctions reduces the volume of trading as well as reduces the link between the value of private information and the amount of insider trading.

\section{Data and Methodology}

We study a universe of regulatory news announcements made by U.K. listed companies, constituents of the FTSE All Share index, published between January 1999 and December 2002. Our database of news releases includes all regulatory news published in the Regulatory News Service (RNS), the approved regulatory information service provided by the LSE. The data are hand-collected from Perfect Information. Each record in the database includes date and time of the announcement, company's name and a headline of the announcements. The regulatory news announcements cover all types of information regarding, among others, financial statements, dividends, operating reports, capital structure, restructuring, ownership, company appointments, meetings, deals, transactions and offers. We classify each announcement into two broad and eight specific categories. Earnings announcements that are explicitly associated with insider trading bans, as detailed in Section 2, are classified into the Banned (or Earnings) category. The remaining announcements are classified into the Not Banned category to reflect the fact that they are not associated with the explicitly defined trading ban period. This last category includes Other Results and Dividends, Capital Structure, Restructuring, Ownership, Board Changes, General Business Information and Miscellaneous. Appendix A lists the examples of news items included in each specific category. 
We collect data on insider transactions from Directors Deals Ltd. The data include transaction date, announcement date, company name, transaction type, and price and volume of the transaction. In line with previous studies on insider trading in the U.K. and U.S. (see, e.g., Gregory et al., 1997; and Ravina and Sapienza, 2009) we focus on open-market stock trades, and exclude transactions, such as, exercise of options ${ }^{5}$, script dividends, bonus shares, rights issues and awards made to directors under incentive plans or reinvestment plans, because they are associated with other corporate actions and events and/or they are not initiated by insiders, and hence generally not driven by private information. We then match data on insider transactions with the news database. Our final sample includes 119,179 news announcements and 8,086 insider trading events in 797 firms. In many cases, there is more than one news announcement published by a company on the same day, and we treat multiple announcements made on the same day as one observation. Altogether, we find 78,251 nonconfounding news observations $(65.7 \%$ of the total $){ }^{6}$

We analyze separately good and bad news. We follow Cheng and Lo (2006) and define good (bad) news when the abnormal stock returns on the news announcement are nonnegative (negative). We assume that the market reaction to the disclosure can be observed immediately on the day of the disclosure and on the following day, when the news attracts wider media coverage, particularly if the announcement is made after the stock exchange trading hours. The short event window allows us to avoid contamination of our measure by other events occurring in a larger window around the disclosure. Therefore, the daily abnormal returns are cumulated over days 0 and +1 relative to the news announcement (hereafter referred to as $C A R$ News or $C A R$ ). We use the market model to compute the event

\footnotetext{
${ }^{5}$ Even though one can argue that insiders may strategically time their option exercises, Gregory et al. (1994) document that in the U.K. option exercises are not based on information. For this reason and also to keep our sample of trades comparable with previous studies, we exclude acquisitions of shares through option exercises.

${ }^{6}$ To keep full information on news categories, we assign each observation to all relevant categories to which individual announcements made on the given day were initially assigned. Therefore, the sum of observations in news categories is greater that the total number of news items with unique dates.
} 
period abnormal returns, with the coefficients $\alpha$ and $\beta$ estimated over 260 trading days ending 31 calendar days before the news announcements, and the returns on the FTSE All Share index as the market return. The prices are adjusted for dividends and stock splits and are collected from Datastream. Our final sample includes 39,617 (50.6\%) good and 38,634 (49.4\%) bad news announcements. The good news are fairly evenly distributed over time, with the average number of announcements per company of 13.5 in 1999, 2001 and 2002, and slightly higher at 14.9 in 2000 . The average number of bad news per company ranges from 12.3 in 2002 to 15.8 in $2000 .^{7}$ The pattern in bad news is consistent with the behavior of the stock market and general economic conditions that deteriorated significantly after the collapse of the dot-com bubble in 2000.

Figure 1 illustrates the distribution of buy (sell) transactions over 25 weeks before good (bad) news. The number of transaction in each week is scaled by the average weekly number of transactions over the 25 -week period. Generally, the number of buy transactions before good news announcement is relatively constant longer in advance of the announcement, and increases 4 weeks immediately before the disclosure. The pattern of sells is slightly different. The number of transactions gradually decreases until about four weeks before the news announcement, and then rises sharply in the run-up to the disclosure. Altogether, the evidence shows that insider trading changes before news announcements and insiders use their foreknowledge to trade profitably in the direction of the news. The sharp increase in trading can be observed about four weeks before the disclosure, consistent with our arguments on the short-lived nature of inside information ahead of many types of announcements.

[Figure 1 about here]

\footnotetext{
${ }^{7}$ For space consideration the detailed results are not tabulated and available upon request.
} 
The evidence in Figure 1 strengthens our argument to look at trading decisions in short windows before news announcements, and taken together with the (at least) 30-day trading ban periods before earnings announcements outlined in Section 2, motivates our research design. While there is no explicit trading ban before the announcement of any non-earnings information, we assume that the 30 calendar-day period before every announcement reflects the time when insiders may be expected to have information advantage. Therefore, to proceed to the tests of our hypothesis, each news observation is matched with insider transactions in the news-announcing firm within 30 calendar days before the news announcement day. We then define two main variables to reflect the magnitude of trading before the news announcement. For each good news announcement, we calculate the percentage Net Buying as the number of shares bought less the number of shares sold by the firm's insiders over the 30 calendar days before the announcement, scaled by the number of shares outstanding on the day of the announcement. ${ }^{8}$ A positive value of the variable indicates that insiders increase their holdings in the company, possibly trading on the foreknowledge of the favorable news (news triggering non-negative $C A R$ ). Similarly, for bad news announcement we define the percentage Net Selling as the number of shares sold less the number of shares bought by the firm's insiders, scaled by the number of shares outstanding. As in the case of good news, a positive value of the variables reflects insiders' trading consistent with the direction of the forthcoming news. The approach to aggregate trading by all insiders in the announcing firm follows previous studies on the decision to trade or not (e.g., Piotroski and Roulstone, 2008; Roulstone, 2008) and is based on the notion that insiders trading on private information will,

\footnotetext{
${ }^{8}$ Scaling by shares outstanding (firm size) follows Roulstone (2008). In light of the evidence that the information content of insider trading differs with the level of insider ownership (e.g., Hillier and Marshall, 2002; Fidrmuc et al., 2006), it would be interesting to look at the magnitude of trading scaled by directors' holdings. Unfortunately we have very much incomplete information on the holdings to follow that route. Also, scaling by insider ownership creates some empirical problems when the (initial) holding is zero or very low.
} 
on average, increase holdings before good news and decrease holdings before bad news. ${ }^{9}$ Also, we believe that by netting buyers and sellers we do not lose much information because for the majority $(92.6 \%)$ of news announcements preceded by insider trading, trading goes in one direction only (i.e., there are only buy or only sell transactions). To explore the trading decisions further, in additional tests we also look separately at trading by selected individuals in the firm (CEO and Chairman).

We complement the analysis with further tests that investigate the occurrence of insider trading in the direction of the forthcoming news. We, thus, define a dummy variable equal to one if Net Buying before a good announcement is positive or Net Selling before bad news is positive, and zero otherwise. If this dummy variable is equal to one, the news observation is denoted as News Preceded by Insider Trading, otherwise they are News without Insider Trading. ${ }^{10}$ Our final sample includes 4,083 good news $(10.3 \%$ of all good news) and 1,262 bad news (3.3\% of all bad news) preceded by insider trading.

We estimate the following OLS regression to analyze the determinants of the magnitude of trading before news announcements, separately for good and bad news (for simplicity of the notation subscript $i$ is omitted):

Net Trading $=\beta_{0}+\beta_{1}$ LnSize $+\beta_{2}$ Market-to-Book $+\beta_{3}$ Past Return

$$
+\beta_{4}|C A R|+\beta_{5} C A R^{2}+\varepsilon
$$

To test for the occurrence of trading, that is, to determine when insiders are net buyers before good news announcements and net sellers before bad news announcements, we run the following logit regressions separately for good and bad news:

\footnotetext{
${ }^{9}$ In untabulated tests we find that $58 \%$ of the news with insider trading are preceded by one trade, $21 \%$ of the news are preceded by 2 trades, and the remaining $21 \%$ of the news are preceded by 3 or more trades. It may be interesting to investigate if individual insiders follow with trading if they learn about trading by their colleagues, or, on the contrary, decide not to trade if their colleagues trade not to attract too much attention. Nevertheless, such behavior, even though not investigated in detail in our paper, is consistent with our hypothesis and research design.

${ }^{10}$ Note that the description News without Insider Trading does not necessary refer to news observations not preceded by any insider transactions. It also refers to good news preceded by net selling and bad news preceded by net buying, as well as to news for which the number of shares purchased and sold over the previous 30 calendar days are equal.
} 
$\operatorname{Prob}($ Trading $=1)=\operatorname{logit}\left(\gamma_{1}\right.$ LnSize $+\gamma_{2}$ Market-to-Book $+\gamma_{3}$ Past Return

$$
\left.+\gamma_{4}|C A R|+\gamma_{5} C A R^{2}+\eta\right)
$$

Net Trading in Equation (1) is Net Buying in the good news sample and Net Selling in the sample of bad news. Trading in Equation (2) is an indicator variable equals to one for News Preceded by Insider Trading and zero for News without Insider Trading.

All models are estimated with firm fixed effects which allow us to control for unobservable firm characteristics that may drive differences in trading behavior between firms, such as, for example, firm-specific insider trading restrictions or policies (see, Ravina and Sapienza, 2009). In the case of trading by corporate insiders in the U.K. it is particularly important given the required clearance to deal granted by the chairman or designated director, as described in Section 2. By including the firm fixed effects, we compare trading within the same firm level institutional setting. ${ }^{11}$ Standard errors of the coefficients in all regressions are adjusted for clustering at the firm level to control for non-independence of observations within a firm.

We focus on the coefficients of $|C A R|$ and $C A R^{2}\left(\beta_{4}, \beta_{5}, \gamma_{4}\right.$ and $\gamma_{5}$ in Equations (1) and (2) above). Assuming that insiders know the information content of the disclosure and can predict how the market will react when the disclosure is made, their strategic trading on this information will be reflected in the link between the probability and/or magnitude of trading and $C A R$. We expect $\beta_{4}$ and $\gamma_{4}$ to be positive to reflect the higher probability of trading ahead of news with a larger market impact, and we expect $\beta_{5}$ and $\gamma_{5}$ to be negative to reflect the lower propensity to trade on disclosures with a very significant impact that are more likely to attract regulatory attention. Following the arguments of asymmetric risk of regulatory scrutiny with regard to trading before good and bad news (Cheng and Lo, 2006), we expect that the

\footnotetext{
${ }^{11}$ As a robustness test we re-run the regressions without fixed effects. The major results (unreported and available upon request) and conclusions are unchanged.
} 
disincentives to trade profitably on private information before bad news are relatively stronger than for trading before good news.

We control for the firm's size, market-to-book ratio and prior stock return. Seyhun (1986) finds that the value of stock trading by insiders in negatively related to firm size. On the other hand, insider transactions can be associated with portfolio rebalancing needs if insiders have large stock and stock option holdings, and the holdings are positively correlated with firm size (Huddart et al., 2007). Therefore we have no prior expectations regarding the sign of $\beta_{1}$ and $\gamma_{1}$. By including Market-to-Book and Past Return we control for the welldocumented insiders' contrarian behavior (Seyhun, 1992a; Rozeff and Zaman, 1998; Jenter, 2005). Previous literature finds that insiders tend to buy stocks after weak past stock price performance and sell after good performance, and similarly insider trading patterns change across market-to-book groups. Insiders tend to sell glamour (high market-to-book) firms and buy value (low market-to-book) firms. Based on these findings, we expect the coefficients $\beta_{2}$, $\beta_{3}, \gamma_{2}$ and $\gamma_{3}$ to be negative in our regressions on the sample of good news, as insider buying is expected to decrease when the market-to-book ratio and past returns increase, but positive in the sample of bad news, as stock selling by insiders is expected to increase for high marketto-book stocks and stocks with strong past performance.

We also run a set of regressions that extend specifications of models (1) and (2) and include additional corporate governance and compensation variables:

Net Trading $=\beta_{0}+\beta_{1}$ LnSize $+\beta_{2}$ Market-to-Book $+\beta_{3}$ Past Return $+\beta_{4}$ LnGrants

$$
\begin{aligned}
& +\beta_{5} \text { Board Independence }+\beta_{6} \text { CEO/Chairman Duality }+\beta_{7} \text { Ln Board Size } \\
& +\beta_{8}|C A R|+\beta_{9} C A R^{2}+\varepsilon
\end{aligned}
$$

$\operatorname{Prob}($ Trading $=1)=\operatorname{logit}\left(\gamma_{1}\right.$ LnSize $+\gamma_{2}$ Market-to-Book $+\gamma_{3}$ Past Return $+\gamma_{4}$ LnGrants

$$
\begin{aligned}
& +\gamma_{5} \text { Board Independence }+\gamma_{6} \text { CEO/Chairman Duality }+\gamma_{7} \text { Ln Board Size } \\
& \left.+\gamma_{8}|C A R|+\gamma_{9} C A R^{2}+\eta\right)
\end{aligned}
$$


Stock and option grants control for diversification motives of insider trades, in particular sells. Ofek and Yermack (2000) argue that for efficient diversification of their portfolios, insiders should sell an appropriate amount of current holdings in response to new grants. Consequently, we expect $\beta_{4}$ and $\gamma_{4}$ to be positive in the regressions run for the bad news subsample. Taking into account the monitoring role of the board, its size can be considered an indicator of the governance quality. It is documented that smaller boards are more effective in monitoring (e.g., Yermack, 1996). We expect low board independence, CEO/Chairman duality and large boards to reflect poorer firm level governance standards, resulting in more widespread trading on private information. Consequently, we expect $\beta_{5}$ and $\gamma_{5}$ to be negative and $\beta_{6}, \beta_{7}, \gamma_{6}$ and $\gamma_{7}$ to be positive. Ln Board Size also proxies for the number of insiders in the firm which may influence the probability and amount of trading we observe.

The variables are defined in detail in Appendix B. The relevant accounting and financial data are collected from Datastream. We use Boardex for governance and compensation variables, but the data are limited to 587 (73.7\%) of our sample firms, reducing the sample to 27,735 good news and 27,459 bad news $(70.0 \%$ and $71.1 \%$ of the initial sample, respectively).

\section{Empirical results}

\subsection{Descriptive Statistics and Univariate Analysis}

Table 1 provides the descriptive statistics of our sample. The average magnitude of the market reaction to announcements $(C A R)$ is similar for good and bad news, with the mean (median) of $3.7 \%(1.8 \%)$ for good news and $-3.6 \%(-1.6 \%)$ for bad news, but there is a difference in the amount of insider trading before the release of good and bad news. In both absolute and relative terms, there are many more cases of insider trading in the direction consistent with the information content of the news when the news is good. In the group of bad news we also find 
that insiders trade before news with a smaller market impact. The mean (median) CAR for bad news preceded by insider trading is $-2.5 \%(-1.4 \%)$, which is significantly lower in the magnitude from the mean (median) $C A R$ for news without insider trading equal to $-3.6 \%$ (1.7\%). Together with the result of less prevalent insider trading before unfavorable news announcement, these findings clearly document that insiders are more cautious when making trading decisions before bad news announcements, possibly due to the asymmetric effect of good and bad news on the wealth of outside investors. This result is in line with our expectations. Insider trading before good news announcement is rather not affected by the information content of the forthcoming disclosure. Even though the mean $C A R$ for news preceded by insider trading is lower from the mean $C A R$ for good news without insider trading (3.5\% versus $3.7 \%$ ), the reversed is true for sub-sample medians.

[Table 1 about here]

To illustrate the relative importance of profits that insiders can make from trading ahead of announcements, we compare $C A R$ of news in our sample with the long term abnormal returns on directors' share trading. Based on U.K. data, Hillier and Marshall (2002) report the average 120 -day cumulative abnormal return of $7.4 \%$ following insider purchases and $-6.3 \%$ for insider sales. Considering that the mean (median) $C A R$ for good news in our sample is $3.7 \%(1.8 \%)$ and for bad news it is $-3.6 \%(-1.6 \%)$, deciding not to trade before the news and postponing the trade until after the news announcement can reduce the longer term trading profits substantially. Are the profits made from trading ahead of news announcements also important in monetary terms? We are only able to estimate the profits (or avoided losses for sell transactions) for cases when the trading is actually observed. We first multiply the value of every trade executed before the news announcement (taken as the negative value for sells) by CAR News. Note that this is a conservative estimate as it only looks at profit, or in fact abnormal profit, made over the two days around the news disclosure. We then sum the 
profits made by every insider every year. For many cases the profit from insider trading is not large, possibly reflecting the deterring effect of regulations. The median profit is only GBP 80. However, for the top $25 \%$ of individuals the annual profit exceeds GBP 1,099 , and for the top $10 \%$ it goes above GBP 5,667 . When scaled by the insider's compensation, for the top $25 \%$ of cases the profit exceeds $1.1 \%$ of basic salary ( $0.8 \%$ of total compensation), and for the top $10 \%$ of cases it reaches a substantial $6.3 \%$ of salary $\left(5.7 \%\right.$ of total compensation). ${ }^{12}$

The univariate analysis of differences in other characteristics presented in Table 1 reveals some additional interesting results. Consistent with previous evidence, insiders appear to adopt contrarian strategies as their buying propensity before good news is concentrated in stocks with weaker past performance $(-5.7 \%$ vs. $3.8 \%)$ and lower market-to-book ratios $(1.28$ vs. 3.39), and they sell before bad news in mainly good companies (past stock returns of $33.8 \%$ vs. $10.6 \%$, and market-to-book of 6.10 vs. 3.55$)$. For both good and bad news we find more insider trading in larger stocks. The diversification motive of trading is not confirmed as we find that, generally, insider trading is observed in firms with lower stock and option grants. However, we cannot conclude that insiders do not diversify their portfolios in response to equity based compensation, as they may be selling in other periods and not immediately before news announcements. The results for corporate governance characteristics are somewhat mixed. In contrast to the expectations, we find that news with insider trading are concentrated in firms where the roles of CEO and Chairman are split, which is considered a better quality governance provision. On the other hand, for bad news sample we find a highly significant difference in board independence between news with and without insider trading. There is more insider trading in firms with less independent board, consistent with the argument that insider trading is more prevalent in firms with a lower quality of corporate

\footnotetext{
${ }^{12}$ For space considerations the detailed results are not tabulated and available upon request.
} 
governance. Interestingly, we also find more insider trading in firms with larger boards, possibly reflecting weaker monitoring (Yermack, 1996). ${ }^{13}$

Table 2 reports the distribution of news across specific news categories, their mean and median $C A R$, and the extent of insider trading before announcement of news across the categories. The news announcements are evenly distributed between good and bad news subsamples, and the distribution of news across specific news categories is similar in good and bad news groups. Miscellaneous is the largest category, followed by Ownership and Restructuring news. Not surprisingly, Earnings are the most price-sensitive announcements triggering on average 5.9\% abnormal return for good news and $-7.6 \%$ abnormal returns if the news is negative. Our results indicate though that insiders are constrained by the regulations as their likelihood of trading before Earnings announcements is very low. Consistent with Hillier and Marshall (1998), our results indicate that there are only few cases (39 out of 1,733 good Earnings news and 3 out of 1,707 bad Earnings news) of trading in the ban period. Overall, as outlined above, a larger proportion of good news is preceded by insider trading compared to bad news, and this holds across all news categories.

[Table 2 about here]

Two news categories with the smallest average market reaction in the good news subsample (Capital Structure and Ownership) have the largest proportion of news releases preceded by insider trading, suggesting that insiders tend to be net buyers before news that generally have a lower information content and hence possibly are less exposed to the risk of regulatory scrutiny. However, looking at the trading patterns within the news categories, the group of announcements related to Ownership is the only group in which insiders buy before significantly more positive news. Beyond that, the analysis of the differences in the strength of the forthcoming good news and the decision to trade does not reveal any clear patterns. The

\footnotetext{
${ }^{13}$ Because of the specific distributions of Board Independence, CEO/Chairman Duality and Board Size (the observations take very few values of the variable and there are many observations at the median), the results of the Wilcoxon test for those variable should be interpreted with caution.
} 
findings related to bad news reinforce our conclusions from Table 1. Across all news categories, insiders are net sellers before releases with smaller market impact, with the difference being highly significant in six out of eight categories. Furthermore, similarly to good news, the largest proportion of news preceded by insider trading is observed in categories that contain news with, on average, lower market impact (Capital Structure and Ownership).

In sum, our results so far suggest that insiders strategically time their trading before news announcement, implying that, before trading, they consider the potential risk of regulatory scrutiny and/or lost reputation. First, trading bans are effectively enforced and we find virtually no insider trading before earnings announcements. Second, because of the asymmetric risk of regulatory scrutiny in case of insider selling and buying (Cheng and Lo, 2006), we observe less insider trading before negative than positive news and thus, managers are likely to try to distance themselves from unfavorable disclosure. Third, the trading before news releases is concentrated before news releases that trigger a lower impact, particularly in the case of bad news. The possible non-linear relation between the propensity to trade on private information and the market impact of the information is addressed in the regression analysis discussed in the following section.

\subsection{Regression Analysis}

While the discussion in Section 5.1 is based on the analysis that primarily looks at the occurrence of insider trading, the regression results presented in Panel A of Table 3 shed more light on the determinants of the magnitude of insider trading before news releases in good and bad news samples. The dependent variable in the sample of good news is the percentage Net Buying, defined as the number of shares bought less the number of shares sold by the firm's insiders over 30 calendar days before the news release, scaled by the number of 
shares outstanding. Correspondingly, the dependent variable in the sample of bad news is the percentage Net Selling, defined as the number of shares sold less the number of shares bought, scaled by the number of shares outstanding. We find that insiders trade profitably using the foreknowledge of the information content of the disclosure before good news announcements. The coefficient of $|C A R|$ News is positive and significant, suggesting that that the amount of insider buying before the announcement increases as the information content of the news increases. We also find some evidence consistent with the strategic trading and the trade-off between incentives to capitalize on the foreknowledge and the disincentives created by the risk of regulatory scrutiny and lost reputation. When we control for equity based compensation and firm level governance characteristics, we find that the coefficient of $C A R^{2}$ News is negative and significant suggesting that when the market reaction to the news release is very large, the potential risks of regulatory scrutiny increase and the insiders' propensity to trade on the information starts to level off. These results imply a turning point to be $54.5 \%$, which is in the tail of the distributions of $C A R$, and suggests that in the range of $C A R$ we observe, the amount of buying ahead of good news increases with the price significance of the news, but it does so in a non-linear fashion. The link between trading and the information content of the news weakens as the information content increases. The finding is similar to the result in Piotroski and Roulstone (2008) who also find that the turning point of insiders' propensity to trade is in the extreme upper tail of the distribution of earnings news they analyze. In the next two regression specifications, we divide the news into news associated with explicitly defined trading ban periods (Banned) and news without the ban periods (Not Banned). As expected, we find that insiders are likely to adopt the strategic trading behavior only in the Not Banned category where the decision to trade depends more on their interpretation of the news which is not explicitly regulated by the Model Code of the London Stock Exchange presented in Section 2. 
[Table 3 about here]

The remaining results indicate that firm size and market-to-book do not affect insiders' buy trades decision. The corporate governance factors appear to have also a marginal effect on the decision, suggesting that insider trading is independent of the board characteristics. In particular, we find that equity based compensation and board composition are not related to the magnitude of buying ahead of good news announcements. The results indicate that only board size affects positively insiders' decision to buy. Instead, the results show that the coefficient of past returns is negative and significant, suggesting that insiders buy mainly in firms with negative past returns, and that they adopt contrarian strategies. Brennan and Cao (1996) suggest that contrarian investors are likely to be informed. Our results provide further evidence supporting the information content of the trading by insiders.

The findings on the determinants of the amount of net selling before bad news releases do not reveal any strongly significant link between net selling and the market impact of the forthcoming disclosure. The coefficient of $|C A R|$ is negative but insignificant, while the coefficient of $C A R^{2}$ is positive and significant at the 0.1 significance level. These results provide some weak evidence that there is more insider trading before more significant bad news. When we split our sample into Banned and Not Banned news, we find significant relationship between trading and the importnace of the news in the Banned category. However, due to the very small number of observations with trading in that group, the results are not meaningful. The relationship in the Not Banned category is weaker compared to the full sample. The result can corroborate arguments in the insider trading literature that insider selling is largely motivated by liquidity and portfolio diversification reasons and less driven by private information, in line with a number of event study findings of no or little stock price changes following insider sales (see, e.g. Ravina and Sapienza, 2009; and Fidrmuc at al., 2006, for the latest evidence from the U.S. and U.K., respectively). Our results, however, do 
not preclude the explanation that insiders strategically choose to refrain from trading before bad news to avoid the risk of regulatory scrutiny.

The remaining results indicate also that insiders' sell trades are not related to their firm's market-to-book. The impact of firm's governance structure is also relatively weak. However, in contrast to the buy trades, our results indicate that insiders sell in large firms, but they do not adopt contrarian strategies, as the coefficient of past returns is positive and not significant. Overall, our results indicate that the characteristics of firms in which they buy before good news are different from those in which they sell before bad news announcements. However, the low R-square of our regressions suggests that these characteristics explain only a very small proportion of the trading behavior of insiders in our sample.

We expand further this analysis by reporting in Table 3, Panel $\mathrm{B}$, the logit results to analyze the occurrence of insider trading. We test whether insiders are net buyers before good news and net sellers before bad news. ${ }^{14}$ In the sample of good news we find that the decision whether or not to buy before the favorable disclosure, unlike the decision how much to buy analyzed in Panel A of Table 3, does not depend on the expected market impact of the forthcoming disclosure. The coefficients of $|C A R|$ and $C A R^{2}$ are not significantly different from zero. The significant coefficients in the Banned group have little meaning as there are very few observations with insider trading in that category. On the other hand, there is a strong link between the probability of selling and the information content of the forthcoming announcement in the sample of bad news. The results of the multivariate regressions confirm the findings at the univariate level presented in Section 5.1. We find that insiders are less likely to trade ahead of the bad news when the news is important, as reflected in the negative and significant coefficient of $|C A R|$. However, the coefficient of $C A R^{2}$ is significant and positive which indicates that the disincentive starts to diminish with the importance of the

\footnotetext{
${ }^{14}$ Note that throughout the paper the number of observation reported for logit regressions is lower than for the OLS model. This is because in the estimation of fixed effect logit, firms with all positive or all negative outcomes are dropped.
} 
news. Still, the minimum of the estimated logit function with respect to $|C A R|$ in the model without compensation and governance control variables is found to be at $|C A R|=84.5 \%$, which indicates that indeed we are looking at the decreasing part of the curve and the disincentives would die out in the extreme beyond the range of $|C A R|$ we observe. In line with the results in Panel A, we find that the likelihood of selling ahead of news is larger in larger firms. The coefficient of Past Return is negative and significant for the buy trades ahead of good news, and positive and significant for the sell trades ahead of bad news, which provides further evidence on the contrarian strategies adopted by insiders.

Overall, the results presented in Table 3 suggest the following patterns in insider trading decisions. First, in the case of good forthcoming news, we find some evidence that insiders strategically choose the amount of shares bought, increasing their purchases as the price impact of the news goes up but limiting the amount of shares purchased as the news becomes extreme. We argue that the decision is driven by the trade-off between the incentives to capitalize on the information content of the disclosure and the potential costs of regulatory scrutiny and lost reputation. We also find that it is the magnitude rather than incidence of trading that is strategically chosen. On the other hand, the incentives and disincentives to sell before bad news are different. We uncover that insiders strategically choose whether to sell rather than how much to sell. The probability of insider selling significantly decreases with the importance of the forthcoming news. We conjecture that insiders' decisions are strongly affected by the risk of a regulatory action against them when they sell on private information and hence they want to avoid any suspicion and decide not to trade at all. Therefore, the decision to trade or not to trade rather than the choice of the amount traded is of primary importance.

We shed more light on the strategic insider trading in Table 4 where we analyze trading around specific news categories. The table allows us to investigate whether the 
behavior depends on the news type, and which news categories drive our results on more aggregate level presented in Table 3. Panel A of Table 4 presents coefficients of the OLS regressions with the magnitude of net buying and net selling as the dependent variable in the good news and bad news sample, respectively. We find that the non-linear relation between the amount traded and $C A R$ in the sample of good news documented in Table 3 is mainly driven by releases of news on Other Results and Dividends, Restructuring news and General Business Info, for which the coefficient of $|C A R|$ is positive and the coefficient of $C A R^{2}$ is negative. As reported in Table 2, these three groups of good news are, on average, most pricesensitive. Considering that they are therefore most likely to attract regulatory scrutiny and investor attention, one would expect insiders to trade strategically before these news announcements and carefully consider their trading decisions. The results also indicate a decrease in insider buying ahead of Capital Structure news announcements, but at a diminishing rate, as the significance of the news increases. The results across other news categories are mixed. In the sample of bad news, the link between net selling and the information content of the disclosure is weak.

\section{[Table 4 about here]}

The results of the logit analysis focused on the probability of trading across different news categories are reported in Panel B of Table 4. The signs of the estimated coefficients of $|C A R|$ and $C A R^{2}$ differ across news categories in the sample of good news, possibly leading to insignificant relationship between the probability of insider trading and CAR reported in Table 3. Looking at the coefficients that are significant at least at the 0.05 level, we find that the probability of trading increases in a non-linear fashion with the importance of news in the Ownership category, but decreases, also non-linearly, for Other Results and Dividends. For Capital Structure news, the probability of buying increases linearly, and for Restructuring news it decreases linearly with the information content of the forthcoming news. In the bad 
news sample we find a strong negative and non-linear relation between $C A R$ and the propensity to sell for Other Results and Dividends news and for General Business Info. As presented in Table 2, Other Results and Dividends and General Business Info are highly price-sensitive disclosures, second only to Earnings announcements associated with explicit trading bans. Since it is generally accepted that such announcements attract attention of regulators, as well as media interest, the probability of being accused of insider trading is high. Therefore, the result reinforces our earlier arguments and provides further support that the regulatory and legal risks have significant impact on the trading behavior.

The major assumptions of our tests that underlie the interpretations given above are that first, insiders have perfect foresight and can predict how the market will react when the information is publicly released, and second, that cumulative abnormal return measured over days 0 and +1 relative to the news announcement date is a true proxy of the information content of the announcement. This can create potential problems if $C A R$ is contaminated by market reaction to insider trading and can lead to potential endogeneity and reversed causality concerns. For example, one may argue that the market reaction upon the news announcement may be influenced by insider trading in the preceding weeks. Nevertheless, previous studies provide conflicting empirical evidence on the direction in which this reversed causality works. On the one hand, it is possible that insider trades ahead of the announcement preempt some information content of the news, start moving prices in the direction of the expected innovation, and, as a consequence, reduce the information content of the news when it is finally released. The preemption comes from outsiders observing insiders' actions and trading in the same direction or insiders 'mechanically' pushing prices when trading heavily. In either case, insider trading ahead of the announcement leads to a weaker or no market reaction on the news announcement. Evidence consistent with this argument is provided by Damodaran and Liu (1993) in a sample of real estate investment trust reappraisals and Udpa (1996) and 
Roulstone (2008) for earnings announcements. An alternative argument is that insider trading and news releases can be considered complementary signals and, additionally, insider trading (i.e., a change in insider holdings) adds credibility to the forthcoming disclosure. In that case, investors use information on trades preceding the news release to interpret the information content of the release itself and a stronger market reaction is observed around the announcement of news preceded by insider trading. Evidence consistent with this argument is provided, for example, by John and Lang (1991) and Gu and Li (2007).

In light of the mixed previous evidence, the effect of the potential reversed causality on our results is unclear. We argue though that the potential impact of the reversed causality on our results is limited. As we show, generally, we find more insider trading ahead of more significant good news and less insider trading ahead of more significant bad news. Such asymmetry is difficult to reconcile consistently with the arguments of reversed causality presented above, but is in line with our arguments on incentives and disincentives to trade. Also, as it is documented in a range of event studies (e.g., Fidrmuc et al., 2006; Ravina and Sapienza, 2009), insider selling is generally not informative therefore it is difficult to argue that in our sample insider selling would preempt the information content of bad news. Roulstone (2008) provides a more thorough econometric analysis of the potential endogeneity between insider trading and market reaction to earnings announcements. However, we are unable to address the endogeneity issue in our empirical tests, as we cannot find appropriate and valid instruments for stock price reaction $(C A R)$ in such a diverse and comprehensive set of corporate announcements.

Still, we are aware that our results should be treated with some caution. In Section 6.3 below we provide some robustness tests that shed more light on the impact of the choice of the window over which we measure $C A R$ on our findings. 


\section{Further Empirical Tests}

\subsection{Regulatory Change and the Costs of Trading}

The legal costs and hence disincentives to trade on private information are difficult to measure. However, a change in insider trading regulations provides a natural experiment because it can be treated as an exogenous shock to the costs of trading. If the costs indeed play a role in the decision to trade or not to trade on the foreknowledge of a proximate disclosure, we should observe a change in managers' trading decisions as a response to the regulatory change. The previous insider trading literature provides evidence that the stock trading behavior by U.S. managers changed around the enactment of the Insider Trading and Securities Fraud Enforcement Act (1988) and the Securities Enforcement Remedies and Penny Stock Reform Act (1990). The objectives of the Acts were to enhance the deterrence measures against insider trading, improve detection and increasing penalties associated with insider trading. Piotroski and Roulstone (2005) document that the amount of trading by managers after the enactment of the new laws has a weaker association with contemporaneous earnings innovations, and a stronger association with the following year's earnings information. Garfinkel (1997) finds that, following the regulatory changes, insiders tend to postpone trading until after earnings disclosures. Taken together, the results of both studies can be interpreted as evidence that a change in the regulations potentially changes the perceived legal costs associated with trading on near-term news.

As outlined in Section 2, our sample period covers a similar change to the regulatory regime in the U.K. The new regulations on market abuse, including insider trading, were introduced by the Financial Services and Markets Act 2000 and apply to misconduct on or after December 1, 2001. The objectives of the new regulatory regime were similar to the developments in the U.S. in 1988 and 1990. The new regime was expected to provide a clear 
statement of the standards for market participants, improve the enforcement of insider trading regulations and make the penalties more imminent even for less severe breaches of rules.

Following Piotroski and Roulstone (2005), we use the change in the regulations to classify our observations into two enforcement regimes: low enforcement (before December 1, 2001) and high enforcement (after December 1, 2001). We expect the new regulations to increase the risk of a regulatory action and a penalty for trading on private information. Consequently, we may observe a lower association between the amount of trading or the occurrence of trading and the market impact of the announcement, a decrease in trading ahead of news with very large market impact and/or overall less trading ahead of news disclosures. To test the impact of the new regulations we extend our basic regressions to allow the coefficients of $|C A R|$ and $C A R^{2}$ to differ between the low and high enforcement periods. Specifically, we add to the regressions cross-products of $|C A R|$ and $C A R^{2}$ with a dummy variable POST which is equal to one for news announcements released on or after December 31, 2001, i.e. announcements for which we observe insider trading from December 1, 2001 onwards (the date when new rules came in force). POST is equal to zero otherwise. Additionally we add POST to the regression to check for possible changes in the amount or probability of insider trading in the new regime. The results are reported in Table 5.

[Table 5 about here]

We find some statistically significant evidence of the impact of the regulatory change on the perceived costs of trading in the regressions explaining the amount of net buying in the good news sample reported in Panel A of Table 5. We find that the non-linear effect reflecting diminishing incentives to trade as the event becomes extreme is a result of the higher enforcement regime after December 2001. Before the change in regulations, insiders traded more on more significant news as reflected in the positive coefficient of $|C A R|$ and insignificant coefficient of $C A R^{2}$. After the change in regulations, the incentives to trade on 
less price-sensitive information increased (positive coefficient of $|C A R| \times P O S T$ ), but the impact of disincentives became visible for more significant news (negative coefficient of $\left.C A R^{2} \times P O S T\right)$. As expected the results are driven by the group of news other than earnings releases which further supports the importance of an insider's own interpretation of the signal and individual decision to trade or not. Insiders are explicitly banned from trading ahead of earnings announcements. There is some further evidence on the impact of new enforcement regime in the logit analysis in the bad news subsample presented in Panel B of Table 5. Generally, the probability of insider selling ahead of bad news decreases, but at a diminishing rate, as the significance of the news increases. The results taking into account the change in regulations reveal that in the stricter regime the reduction in the disincentives eased as reflected by the negative coefficient of $C A R^{2} \times P O S T$. The results on the impact of the change in regulations in other specifications are inconclusive.

The results are subject to two caveats. First, the new regime came in force in December 2001, but the changes were announced and consulted earlier. Hence any changes to insider behavior could be gradual and we may not be able to detect them in our relatively short sample window of four years. Second, as documented by Bhattacharya and Daouk (2002) the economic impact of insider trading regulations can only be observed around the first enforcement. As mentioned in Section 2, the FSA imposed the first civil penalty in the new regime only in February 2004.

\subsection{Trading by CEO and Chairmen and the Effect of Reputation}

All previous results are based on aggregated trading by all insiders in the firm that announces the news. In this section, we look at trading by selected individuals - CEOs and Chairmen. First, it allows us to investigate whether trading behavior differs depending on the position of the insider within the firm. Second, looking at individuals, we are able to control 
for their characteristics that may shed more light on the factors behind trading decisions. As we outline in our hypothesis, the disincentives to trade include the risks of reputational and political costs. When looking at individuals, we are able to analyze two proxies for reputation - the number of boards given individual sits on and his/her age. If the risk of losing reputation indeed plays a role, we should see less insider trading by individuals sitting on many boards and by older individuals. The results are reported in Table 6 . To save space, we report only regressions that separately include Banned and Not Banned news. The unreported results in the full sample are similar to the results for the Not Banned category. The full results are available upon request.

[Table 6 about here]

Altogether, we find some evidence of the reputation effects. We find that Chairmen withhold from selling ahead of bad news when they sit on more boards, as reflected in the strongly significant negative coefficient of \# Boards in the logit results in Panel B. It is consistent with the larger jeopardy when trading on bad news compared to good news. We find also that CEOs sell more ahead of bad news when they get older. This is not consistent with the reputational argument but may rather reflect liquidity trading and cashing out by older executives. We also find some interesting results on the link between trading and $C A R$. CEOs are found to make informed trading decisions. The amount of buying ahead of good news confirms our hypothesis on the non-linearity. The amount of selling by CEOs is independent of $C A R$ but the decision to sell analyzed in the logit regression is non-linear. Interestingly, the results are different from the results in the full sample. We find that CEOs sell more when the content of the news increases, but withhold from selling when the news becomes large. The turning point is $|C A R|=12.3 \%$. For Chairmen, generally, the link between insider trading and CAR is weaker than for supposedly better informed CEOs. We 
find some evidence though on Chairmen's strategic decision related to the amount of buying before good news announcement.

To summarize, we find some evidence that the reputational risks play a role in the insider trading decisions by Chairmen. We also find strong evidence on strategic informed trading by CEOs, the individuals with the best information in the firm. These results are likely to be specific to the U.K. market as the roles of the CEO and the Chairman tend to be split following the various corporate governance codes recommendations, starting with Cadbury in 1992. In addition, Chairmen in the U.K. are likely to be non-executive, and thus likely to have less information than CEOs.

\subsection{Preemption of the Information Content of News}

In the main body of the paper we use cumulative abnormal return measured over days 0 and +1 relative to the news announcement date as our proxy for the information content of the news disclosure. We want the window to be narrow enough not to capture anything that may be happening further away from the announcement, which may move prices. We acknowledge however that this short-window measure may not be precise. First, there may be leakage ahead of the announcements moving prices before day 0. Second, insider trades ahead of the announcement may preempt some information content of the news, as discussed in Section 5.2. As a robustness check we re-run our main regressions keeping the left-hand side variable unchanged (as insider trading in the 30 calendar days before the announcement) and changing the window over which we measure our right-hand side CAR. Because, by construction, abnormal returns can only be calculated for trading days, we look at $C A R$ measured over the windows $[-20,+1],[-10,+1]$, and $[-5,+1]$ trading days relative to the announcement day. The window going back 20 trading days is approximately equivalent to the 30-calendar day window. 
The results are presented in Table 7. For space considerations we report only the coefficients of our main variables of interest $\left(|C A R|\right.$ and $\left.C A R^{2}\right)$ and only for regressions that separately include Banned and Not Banned news. Full results are available upon request. Overall, we find that the relationship between the amount of buying and $C A R$ for good news (OLS model) measured over the different windows increases and becomes statistically significant as the observation window shortens converging to our findings on the window $[0,+1]$. We confirm that insiders trade more ahead of the news as the information content of the news increases. We do not find the non-linear effect though. The logit regressions for good news provide evidence that the coefficients of $C A R$ in the Not Banned group measured in longer windows confirm our hypothesis and are in line with the findings from the OLS model. We find some evidence on the non-linear link, in line with the cost-benefit trade-off argument, in the window $[-5,+1]$. In longer windows, we find that, generally, the probability of buying increases, but linearly, as the significance of the forthcoming news goes up. The coefficients of the OLS model for bad news are significant only in the Banned group. However, the small number of observations with trading in that group does not allow drawing meaningful conclusions. This is in line with the main results reported in Table 3 . In the logit regressions for bad news with $C A R$ measured over the $[-20,+1]$ window, we find evidence consistent with our hypothesis for news in the Not Banned group, in which insiders have discretion on whether to trade or not. The probability of selling increases, but at the diminishing rate, as the news becomes more significant. Again, the statistically significant results for the Banned news have to be interpreted with caution.

[Table 7 about here]

To summarize, if we allow for potential information leakage and news preemption in the definition of the window over which we measure the market reaction to news announcements, our main findings hold. We find that the amount and probability of insider 
buying ahead of good news increases, with some evidence of the non-linear increase, as the information content of the news increases. This reflects the increasing incentives to trade profitably, as well as the disincentive effect of regulations when the news becomes extreme. For insider selling before bad news announcements, we find that, if anything, insiders strategically make a decision on whether to trade rather than on how much to trade and avoid trading on price-sensitive information. This is consistent with the larger regulatory and reputation risks associated with trading on negative information. The weaker results for bad news can also indicate that managers try to distance themselves from unfavorable disclosures.

\section{Conclusions}

In this paper we analyze the strategic trading of insiders and the ways insiders use short-lived private information. We argue that the decisions to trade or not to trade on the foreknowledge of corporate news in short windows before news announcements is likely to be taken strategically and will result from a trade-off between the incentives to capitalize on foreknowledge of the information content of the disclosure and the disincentives created by the risk of the regulatory scrutiny and political and reputation costs. We assume that insiders know the information content of the upcoming disclosure and can predict how the market will react when the disclosure is made. The more relevant is the information released to the market, the larger is the profit that insiders can make by trading on this information. However, the jeopardy of a potential regulatory action and the costs of a reputation loss are expected to be higher if the forthcoming news release is highly price-sensitive and, consequently, this may prevent insiders from trading.

We investigate insider trading around the universe of regulatory news announcements in U.K. listed companies included in the FTSE All Share Index between January 1999 and December 2002. Overall, our results show that insiders strategically time their trading before 
news announcement, and we argue that the trading decisions are primarily driven by regulations and potential risks of lost reputation. We find that a larger fraction of good news, compared to bad news, is preceded by insider trading, and that the regulatory trading bans are well enforced and insiders do not trade before earnings announcements. We show that insiders strategically choose the amount of shares bought ahead of good news announcements, increasing their purchases as the price impact of the news goes up, but the amount of shares purchased levels off as the news becomes extreme. In the case of bad news, we find that insiders strategically choose whether to sell rather than how much to sell and the probability of insider selling significantly decreases with the importance of the forthcoming news. We argue that when facing a risk of potential legal action, insiders' primary decision is on whether to trade or not, rather than on the magnitude of trading. To avoid the risk, insiders decide to fully withhold from trading. For both good and bad news, we find that the results on strategic trading are driven by news in, on average, the most price-sensitive categories of announcements, further supporting the argument that the regulatory and reputational risks have a significant impact on insider trading behavior. We also find evidence on clearly pronounced strategic informed trading by CEOs, we show that insider trading patterns change when the regulatory regime becomes stricter, and that insiders with higher reputation at risk limit their trading ahead of bad news. All these findings support our arguments on incentives and disincentives that drive insider trading decision shortly before news announcement.

There are certain limitations of our approach and inherent problems in insider trading research in general. Private information by its nature is not observable and we can only use imperfect proxies for the existence and significance of the information. We use the universe of corporate announcements and assume that insiders know the information ahead of the market. On the one hand, we look at a set of firm-specific news coming from within the company that potentially constitute private information known to insiders. However, in some 
cases the information may be known only to a fraction of corporate insiders or is not known to them in advance at all, such as sudden events outside the firm's control that trigger ad hoc disclosures. Hence, we may be assuming existence of private information while the insiders in fact do not have it. As a consequence, we cannot rule out the possibility that in some cases when we observe no trading, the insiders do not withhold from trading on the basis of the significance of private information but simply because they do not have the information. Furthermore, we look at 30 days rather than a longer time span before the news announcement. We provide evidence on the timing of trading before news releases to support the rationale for our approach, and we also argue that the information advantage associated with many corporate events is short-lived as the news in many cases become public shortly after the firm's insiders know them. Therefore, insiders have a short window of opportunity to trade with the foreknowledge. However, for some specific types of significant information it may also be possible that insiders know the information much in advance and trade as early as many quarters ahead of the announcement (see, e.g., Seyhun and Bradley, 1997; Ke et al., 2003). Hence, we may be observing no trading in the 30-day window and classify the event as no-trade while in fact it is preceded by trading much earlier. Moreover, we may be missing periods in which insiders are informed and have private information in relation to the company, but it is not associated with a news disclosure forthcoming in the next 30 days. For example, there may be private information originating outside the company, such as a significant announcement by another company in the sector, an industry-wide event, or an event or announcement related to the company but coming from outside the firm (e.g., an analyst report or a press report) which we do not cover in our dataset. This could be addressed in an analysis of events defined as stock price movements above a certain threshold rather than news releases (see, e.g. Ravina and Sapienza, 2009). We do not follow that path though because we believe that our approach is more precise in identifying specific pieces of news 
and we limit the risk of including cases of random large price changes not related to any information. Finally, the underlying assumption of our tests is that insiders have perfect foresight and can predict how the market will react when the information is publicly released. This can create potential endogeneity and reversed causality concerns as one may argue that the market reaction upon the news announcement may be influenced (positively or negatively) by insider trading in the preceding weeks. We address these issues in the discussion and interpretation of our empirical results and provide some evidence to show the robustness of our findings. Nevertheless, we are aware that our findings should be interpreted with some caution.

Future research could follow several avenues. First, one could explore in detail when insiders trade ahead of announcements, whether the trades tend to cluster at a certain time before the news, and whether the timing of the trades changes across news with different market impact and across types of news. We provide some preliminary evidence in Figure 1 but a more detailed study of the patterns would be warranted. Second, one could investigate the intra-group dynamics and herding among insiders. It remains open whether individual insiders follow with trading if they learn about trading by their colleagues, or, on the contrary, decide not to trade if their colleagues trade not to attract too much attention. Third, one could explore the strategic timing of insider trading together with the strategic timing of news disclosure. We treat the timing of news announcements as exogenous and we analyze whether insiders strategically trade before the announcements, but it is worth investigating whether or not insiders strategically manipulate both trading and news releases. Finally, we focus on only direct trading in equity. We do not consider trading by insiders in the options and derivatives market. The extent to which all these factors will strengthen or alter our conclusions is a matter of further research. 


\section{References}

Agrawal, A. and T. Cooper (2008), 'Insider trading before accounting scandals'. University of Alabama working paper.

Ausubel, L. M. (1990), 'Insider trading in a rational expectations economy'. American Economic Review, Vol. 80, pp. 1022-1041.

Bettis, J. C., J. L. Coles and M. L. Lemmon (2000), 'Corporate policies restricting trading by insiders'. Journal of Financial Economics, Vol. 57, pp. 191-220.

Bhattacharya, U. and H. Daouk (2002), 'The world price of insider trading'. Journal of Finance, Vol. 57, pp. 75-108.

Brennan, M. J. and H. H. Cao (1996), 'Information, trade, and derivative securities', Review of Financial Studies, Vol. 9, pp. 163-208.

Cheng, Q. and K. Lo (2006), 'Insider trading and voluntary disclosures'. Journal of Accounting Research, Vol. 44, pp.815-848.

Damodaran, A. and C. H. Liu (1993), 'Insider trading as a signal of private information'. Review of Financial Studies, Vol. 6, pp. 79-119.

Fidrmuc, J., M. Goergen and L. Renneboog (2006), 'Insider trading, news release and ownership concentration'. Journal of Finance, Vol. 61, p. forthcoming.

Finnerty, J. E. (1976), 'Insiders and market efficiency'. Journal of Finance, Vol. 31, pp. 11411148.

Fishman, M. J. and K. M. Hagerty (1992), 'Insider trading and the efficiency of stock prices'. The RAND Journal of Economics, Vol. 23, pp. 106-122.

Friederich, S., A. Gregory, J. Matatko and I. Tonks (2002), 'Short-run returns around the trades of corporate insiders on the London Stock Exchange'. European Financial Management, Vol. 8, pp. 7-30. 
Garfinkel, J. A. (1997), 'New evidence on the effects of federal regulations on insider trading: The insider trading and securities fraud enforcement act (ITSFEA)'. Journal of Corporate Finance, Vol. 3, pp. 89-111.

Gregory, A., J. Matatko and I. Tonks (1997), 'Detecting information from directors' trades: Signal definition and variable size effects'. Journal of Business Finance \& Accounting, Vol. 24, pp. 309-342.

Gregory, A., J. Matatko, I. Tonks and R. Purkis (1994), 'UK directors trading - the impact of dealings in smaller firms'. Economic Journal, Vol. 104, no. 422, pp. 37-53.

Gu, F. and J. Q. Li (2007), 'The credibility of voluntary disclosure and insider stock transactions'. Journal of Accounting Research, Vol. 45, pp. 771-810.

Hillier, D. and A. P. Marshall (1998), 'The timing of directors' trades'. Journal of Business Law, pp. 454-467.

--- (2002), 'The market evaluation of information in directors' trades'. Journal of Business Finance \& Accounting, Vol. 29, pp. 77-110.

Huddart, S., B. Ke and C. Shi (2007), 'Jeopardy, non-public information, and insider trading around sec 10-K and 10-Q filings'. Journal of Accounting and Economics, Vol. 43, pp. $3-36$.

Jaffe, J. F. (1974), 'Special information and insider trading'. Journal of Business, Vol. 47, pp. 410-428.

Jenter, D. (2005), 'Market timing and managerial portfolio decisions'. Journal of Finance, Vol. 60, pp. 1903-1949.

John, K. and L. H. P. Lang (1991), 'Insider trading around dividend announcements - theory and evidence'. Journal of Finance, Vol. 46, pp. 1361-1389. 
Kallunki, J.-P., H. Nilsson and J. Hellström (2009), 'Why do insiders trade? Evidence based on unique data on Swedish insiders'. Journal of Accounting and Economics, Vol. 48, pp. 37-53.

Karpoff, J. M. and D. S. Lee (1991), 'Insider trading before new issue announcements'. Financial Management, Vol. 20, pp. 18-26.

Ke, B., S. Huddart and K. Petroni (2003), 'What insiders know about future earnings and how they use it: Evidence from insider trades'. Journal of Accounting \& Economics, Vol. 35, pp. 315-346.

Lee, D. S., W. H. Mikkelson and M. M. Partch (1992), 'Managers trading around stock repurchases'. Journal of Finance, Vol. 47, pp. 1947-1961.

Lustgarten, S. and V. Mande (1995), 'Financial analysts' earnings forecasts and insider trading'. Journal of Accounting and Public Policy, Vol. 14, pp. 233-261.

Manne, H. G. (1966), 'Insider trading and stock market'. Free Press.

Noe, C. F. (1999), 'Voluntary disclosures and insider transactions'. Journal of Accounting \& Economics, Vol. 27, pp. 305-326.

Ofek, E. and D. Yermack (2000), 'Taking stock: Equity-based compensation and the evolution of managerial ownership'. Journal of Finance, Vol. 55, pp. 1367-1384.

Piotroski, J. D. and D. T. Roulstone (2005), 'Do insider trades reflect both contrarian beliefs and superior knowledge about future cash flow realizations?'. Journal of Accounting and Economics, Vol. 39, pp. 58-81.

Piotroski, J. and D. T. Roulstone (2008), 'Evidence on the non-linear relation between insider trading decisions and future earnings information'. Journal of Law, Economics, and Policy, Vol. 4, pp. 409-448. 
Pope, P., R. Morris and D. Peel (1990), 'Insider trading: Some evidence on market efficiency and directors' share dealings in Great Britain'. Journal of Business Finance \& Accounting, Vol. 17, pp. 359-380.

Ravina, E. and P. Sapienza (2009), 'What do independent directors know? Evidence from their trading'. Review of Financial Studies, forthcoming.

Roulstone, D. (2008), 'Insider trading and the information content of earnings announcement'. Working paper.

Rozeff, M. S. and M. A. Zaman (1998), 'Overreaction and insider trading: Evidence from growth and value portfolios'. Journal of Finance, Vol. 53, pp. 701-716.

Seyhun, H. N. (1986), 'Insiders profits, costs of trading, and market-efficiency'. Journal of Financial Economics, Vol. 16, pp. 189-212.

--- (1990), 'Do bidder managers knowingly pay too much for target firms'. Journal of Business, Vol. 63, pp. 439-464.

--- (1992a), 'Why does aggregate insider trading predict future stock returns'. Quarterly Journal of Economics, Vol. 107, pp. 1303-1331.

--- (1992b), 'The effectiveness of the insider-trading sanctions'. Journal of Law \& Economics, Vol. 35, pp. 149-182.

Sivakumar, K. and G. Waymire (1994), 'Insider trading following material news events: Evidence from earnings'. Financial Management, Vol. 23, pp. 23-32.

Udpa, S.C. (1996), 'Insider trading and the information content of earnings'. Journal of Business Finance and Accounting, Vol. 23, pp. 1069-1095.

Yermack, D. (1996), 'Higher market valuation of companies with a small board of directors'. Journal of Financial Economics, Vol. 40, pp. 185-211. 
Appendix A. News Classification

\begin{tabular}{|c|c|}
\hline News Category & News Items \\
\hline Earnings & $\begin{array}{l}\text { Preliminary Annual Results } \\
\text { Interim Results } \\
\text { Quarterly Results }\end{array}$ \\
\hline Other Results and dividends & $\begin{array}{l}\text { Final Results } \\
\text { Operating Reports } \\
\text { Trading Statements } \\
\text { Dividends }\end{array}$ \\
\hline Capital Structure & $\begin{array}{l}\text { Equity Issue } \\
\text { Debt Issue } \\
\text { Transactions in Own Shares } \\
\text { Blocklisting Interim Review } \\
\text { Script Dividends } \\
\text { Debt } \\
\text { Other Capital Structure }\end{array}$ \\
\hline Restructuring & $\begin{array}{l}\text { Mergers and Acquisitions } \\
\text { Demergers } \\
\text { Expansion of Business } \\
\text { Disposals } \\
\text { Interest in Shares }\end{array}$ \\
\hline Ownership & Ownership Changes \\
\hline Board Changes & $\begin{array}{l}\text { Board Changes } \\
\text { Management Appointments }\end{array}$ \\
\hline General Business Info & $\begin{array}{l}\text { Change of Adviser } \\
\text { Agreements } \\
\text { Awards and Cancellations of Contracts } \\
\text { Regulatory Applications and Approvals } \\
\text { Patents } \\
\text { New Products } \\
\text { Research Updates } \\
\text { Net Asset Value } \\
\text { Litigation Issues } \\
\text { Labour Issues } \\
\text { Other Business Information }\end{array}$ \\
\hline Miscellaneous & $\begin{array}{l}\text { Other Appointments } \\
\text { Listing } \\
\text { Other } \\
\text { Observations without a Title }\end{array}$ \\
\hline
\end{tabular}


Appendix B. Definitions of the Variables

\begin{tabular}{|c|c|}
\hline Variable & Definition \\
\hline $\begin{array}{l}\text { Net Buying } \\
\text { (Net Selling) }\end{array}$ & $\begin{array}{l}\text { Number of shares bought less the number of shares sold (the number of shares } \\
\text { sold less the number of share bought) by insiders over } 30 \text { days before the news } \\
\text { announcement, scaled by the number of shares outstanding, multiplied by } 100 \text {. }\end{array}$ \\
\hline CAR News & $\begin{array}{l}\text { Cumulative abnormal return over days } 0 \text { and }+1 \text { relative to the news } \\
\text { announcement. Abnormal returns are market model adjusted. Coefficients of } \\
\text { the market model are estimated over } 260 \text { trading days ending } 31 \text { calendar days } \\
\text { before the news announcement. }\end{array}$ \\
\hline$|C A R|$ News & Absolute value of CAR News. \\
\hline $\begin{array}{l}\mid \text { CAR } \mid \text { Banned } \\
(|C A R| \text { Not Banned })\end{array}$ & $\begin{array}{l}\text { Event period cumulative abnormal return of the news in the group of Banned } \\
\text { (Not Banned) news. }\end{array}$ \\
\hline Past Return & $\begin{array}{l}\text { Return on the stock measured over } 120 \text { trading days ending } 31 \text { calendar days } \\
\text { before the news announcement. }\end{array}$ \\
\hline Size & $\begin{array}{l}\text { Firm's market capitalization in GBP million measured on the day of the news } \\
\text { announcement. }\end{array}$ \\
\hline LnSize & Natural logarithm of Size. \\
\hline Market-to-Book & $\begin{array}{l}\text { Ratio of the market value of shares and book value of shares on the day of the } \\
\text { news announcement. }\end{array}$ \\
\hline Grants & $\begin{array}{l}\text { Sum of volumes of: options, long-term investment plan options (exercisable } \\
\text { and nonexercisable) and long-term investment plan shares granted in the } \\
\text { financial year in which the news was announced, scaled by the number of } \\
\text { shares outstanding. }\end{array}$ \\
\hline LnGrants & Natural logarithm of $1+$ Grants. \\
\hline $\begin{array}{l}\text { Board } \\
\text { Independence }\end{array}$ & $\begin{array}{l}\text { Dummy variable taking value of one if the proportion of non-executive } \\
\text { directors to the total number of board members is greater or equal to } 50 \% \text { in } \\
\text { the financial year in which the news was announced. Equal to zero otherwise. }\end{array}$ \\
\hline $\begin{array}{l}\text { CEO/Chairman } \\
\text { Duality }\end{array}$ & $\begin{array}{l}\text { Dummy variable taking value of one if the same person acts as both CEO and } \\
\text { Chairman in the financial year in which the news was announced. Equal to } \\
\text { zero otherwise. }\end{array}$ \\
\hline Board Size & $\begin{array}{l}\text { Total number of board members including executive and non-executive } \\
\text { directors in the financial year in which the news was announced. }\end{array}$ \\
\hline LnBoard Size & Natural logarithm of Board Size. \\
\hline POST & $\begin{array}{l}\text { Dummy variable equal to one for news observations in the stronger insider } \\
\text { trading regulatory regime introduced in December 2001, and zero otherwise. }\end{array}$ \\
\hline \# Boards & $\begin{array}{l}\text { Number of boards of listed companies the insider sits on in the financial year } \\
\text { in which the news was announced }\end{array}$ \\
\hline Age & Insider's age in the financial year in which the news was announced. \\
\hline
\end{tabular}


Table 1. Descriptive Statistics of News Announcements

\begin{tabular}{|c|c|c|c|c|c|c|c|c|c|c|c|c|c|c|}
\hline & \multicolumn{4}{|c|}{ Full Sample } & \multicolumn{4}{|c|}{ News Preceded by Insider Trading } & \multicolumn{4}{|c|}{ News without Insider Trading } & \multirow{2}{*}{$\begin{array}{c}\begin{array}{c}\text { T-test } \\
(\mathrm{p} \text {-value })\end{array} \\
\text { Mean }\end{array}$} & \multirow{2}{*}{$\begin{array}{c}\begin{array}{c}\text { Wilcoxon } \\
\text { (p-value) }\end{array} \\
\text { Median }\end{array}$} \\
\hline & $\mathrm{N}$ & Mean & Median & $\begin{array}{l}\text { Std. } \\
\text { Dev. }\end{array}$ & $\mathrm{N}$ & Mean & Median & $\begin{array}{l}\text { Std. } \\
\text { Dev. }\end{array}$ & $\mathrm{N}$ & Mean & Median & $\begin{array}{l}\text { Std. } \\
\text { Dev. }\end{array}$ & & \\
\hline \multicolumn{15}{|l|}{ Panel $A$. Good News } \\
\hline CAR News & 39,617 & 0.037 & 0.018 & 0.060 & 4,083 & 0.035 & 0.019 & 0.051 & 35,534 & 0.037 & 0.018 & 0.060 & 0.011 & 0.164 \\
\hline Past Return & 39,617 & 0.028 & -0.020 & 0.578 & 4,083 & -0.057 & -0.079 & 0.465 & 35,534 & 0.038 & -0.012 & 0.589 & 0.000 & 0.000 \\
\hline Size & 39,617 & 3,381 & 224 & 14,122 & 4,083 & 5,606 & 409 & 20,517 & 35,534 & 3,126 & 211 & 13,166 & 0.000 & 0.000 \\
\hline Market-to-Book & 39,617 & 3.170 & 1.880 & 16.535 & 4,083 & 1.282 & 1.690 & 18.305 & 35,534 & 3.387 & 1.910 & 16.306 & 0.000 & 0.000 \\
\hline Net Buying & 39,617 & -0.111 & 0.000 & 0.778 & 4,083 & 0.118 & 0.007 & 0.627 & 35,534 & -0.017 & 0.000 & 0.355 & & \\
\hline Grants $\times 100$ & 27,735 & 0.316 & 0.096 & 0.818 & 3,375 & 0.271 & 0.104 & 0.493 & 24,360 & 0.322 & 0.094 & 0.853 & 0.000 & 0.000 \\
\hline Board Independence & 27,735 & 0.656 & 1.000 & 0.475 & 3,375 & 0.670 & 1.000 & 0.470 & 24,360 & 0.654 & 1.000 & 0.476 & 0.073 & 0.076 \\
\hline CEO/Chairman Duality & 27,735 & 0.267 & 0.000 & 0.442 & 3,375 & 0.254 & 0.000 & 0.435 & 24,360 & 0.269 & 0.000 & 0.443 & 0.063 & 0.066 \\
\hline Board Size & 27,735 & 8.710 & 8.000 & 2.869 & 3,375 & 9.331 & 8.000 & 2.837 & 24,360 & 8.624 & 8.000 & 2.863 & 0.000 & 0.000 \\
\hline \multicolumn{15}{|l|}{ Panel B. Bad News } \\
\hline CAR News & 38,634 & -0.036 & -0.016 & 0.075 & 1,262 & -0.025 & -0.014 & 0.039 & 37,372 & -0.036 & -0.017 & 0.076 & 0.000 & 0.000 \\
\hline Past Return & 38,634 & 0.114 & 0.030 & 0.705 & 1,262 & 0.338 & 0.164 & 0.747 & 37,372 & 0.106 & 0.025 & 0.702 & 0.000 & 0.000 \\
\hline Size & 38,634 & 3,487 & 261 & 14,495 & 1,262 & 7,246 & 545 & 22,651 & 37,372 & 3,361 & 254 & 14,121 & 0.000 & 0.000 \\
\hline Market-to-Book & 38,634 & 3.630 & 2.040 & 14.292 & 1,262 & 6.104 & 3.120 & 15.802 & 37,372 & 3.546 & 2.000 & 14.231 & 0.000 & 0.000 \\
\hline Net Selling & 38,634 & 0.010 & 0.000 & 0.367 & 1,262 & 0.533 & 0.017 & 1.732 & 37,372 & -0.008 & 0.000 & 0.167 & & \\
\hline Grants $\times 100$ & 27,459 & 0.319 & 0.095 & 1.059 & 1,050 & 0.259 & 0.075 & 0.703 & 26,409 & 0.322 & 0.095 & 1.071 & 0.006 & 0.001 \\
\hline Board Independence & 27,459 & 0.649 & 1.000 & 0.477 & 1,050 & 0.515 & 1.000 & 0.500 & 26,409 & 0.654 & 1.000 & 0.476 & 0.000 & 0.000 \\
\hline CEO/Chairman Duality & 27,459 & 0.264 & 0.000 & 0.441 & 1,050 & 0.238 & 0.000 & 0.426 & 26,409 & 0.265 & 0.000 & 0.441 & 0.055 & 0.055 \\
\hline Board Size & 27,459 & 8.742 & 8.000 & 2.857 & 1,050 & 9.810 & 9.000 & 3.506 & 26,409 & 8.700 & 8.000 & 2.820 & 0.000 & 0.000 \\
\hline
\end{tabular}

Notes: This table presents descriptive statistics of news announcements in the samples of Good News and Bad News. Good News (Bad News) is an announcement that yields non-negative (negative) CAR News. In the sample of Good News (Bad News), an announcement is associated with insider trading if there is a positive net amount of shares bought (sold) within 30 calendar days before the announcement (News Preceded by Insider Trading). Differences between News Preceded by Insider Trading and News without Insider Trading are presented using T-test for differences in means and Wilcoxon Two-Sample Test for differences in medians. The sample includes all regulatory news announcements by U.K. listed companies published in the Regulatory News Service (RNS) between January 1999 and December 2002 . See, Appendix B for detailed definitions of the variables. 
Table 2. Descriptive Statistics of CAR News $[0,+1]$ across News Categories

\begin{tabular}{|c|c|c|c|c|c|c|c|c|c|c|c|c|c|c|c|}
\hline & \multicolumn{4}{|c|}{ Full Sample } & \multicolumn{5}{|c|}{ News Preceded by Insider Trading } & \multicolumn{4}{|c|}{ News without Insider Trading } & \multirow{2}{*}{$\frac{\begin{array}{c}\text { T-test } \\
(\mathrm{p} \text {-value })\end{array}}{\text { Mean }}$} & \multirow{2}{*}{$\begin{array}{c}\begin{array}{c}\text { Wilcoxon } \\
\text { (p-value) }\end{array} \\
\text { Median }\end{array}$} \\
\hline & $\mathrm{N}$ & Mean & Median & $\begin{array}{c}\text { Std. } \\
\text { Dev. }\end{array}$ & $\mathrm{N}$ & $\%$ of All & Mean & Median & $\begin{array}{c}\text { Std. } \\
\text { Dev. }\end{array}$ & $\mathrm{N}$ & Mean & Median & $\begin{array}{l}\text { Std. } \\
\text { Dev. }\end{array}$ & & \\
\hline \multicolumn{16}{|l|}{ Panel A. Good News } \\
\hline All & 39,617 & 0.037 & 0.018 & 0.060 & 4,083 & 10.31 & 0.035 & 0.019 & 0.051 & 35,534 & 0.037 & 0.018 & 0.060 & 0.011 & 0.164 \\
\hline Earnings & 1,733 & 0.059 & 0.037 & 0.069 & 39 & 2.25 & 0.052 & 0.032 & 0.057 & 1,694 & 0.059 & 0.037 & 0.069 & 0.526 & 0.649 \\
\hline Other Results and Div & 4,590 & 0.050 & 0.029 & 0.063 & 348 & 7.58 & 0.041 & 0.024 & 0.062 & 4,242 & 0.050 & 0.030 & 0.063 & 0.006 & 0.000 \\
\hline Capital Structure & 4,593 & 0.029 & 0.016 & 0.049 & 720 & 15.68 & 0.029 & 0.016 & 0.041 & 3,873 & 0.029 & 0.016 & 0.050 & 0.849 & 0.226 \\
\hline Restructuring & 7,552 & 0.036 & 0.017 & 0.061 & 589 & 7.80 & 0.035 & 0.021 & 0.054 & 6,963 & 0.036 & 0.017 & 0.061 & 0.821 & 0.009 \\
\hline Ownership & 9,949 & 0.032 & 0.016 & 0.048 & 1,268 & 12.74 & 0.035 & 0.018 & 0.050 & 8,681 & 0.031 & 0.016 & 0.048 & 0.026 & 0.001 \\
\hline Board Changes & 1,906 & 0.033 & 0.016 & 0.048 & 218 & 11.12 & 0.031 & 0.016 & 0.041 & 1,688 & 0.033 & 0.016 & 0.049 & 0.507 & 0.968 \\
\hline General Business Info & 4,369 & 0.052 & 0.029 & 0.076 & 492 & 11.26 & 0.045 & 0.026 & 0.064 & 3,877 & 0.053 & 0.029 & 0.077 & 0.017 & 0.022 \\
\hline Miscellaneous & 11,893 & 0.035 & 0.016 & 0.067 & 922 & 7.75 & 0.035 & 0.020 & 0.054 & 10,971 & 0.035 & 0.016 & 0.068 & 0.712 & 0.001 \\
\hline \multicolumn{16}{|l|}{ Panel B. Bad News } \\
\hline All & 38,634 & -0.036 & -0.016 & 0.075 & 1,262 & 3.27 & -0.025 & -0.014 & 0.093 & 37,372 & -0.036 & -0.017 & 0.076 & 0.000 & 0.000 \\
\hline Earnings & 1,707 & -0.076 & -0.043 & 0.112 & 3 & 0.18 & -0.011 & -0.013 & 0.004 & 1,704 & -0.076 & -0.043 & 0.112 & 0.000 & 0.059 \\
\hline Other Results and Div & 4,339 & -0.073 & -0.030 & 0.130 & 113 & 2.60 & -0.026 & -0.014 & 0.044 & 4,226 & -0.074 & -0.031 & 0.131 & 0.000 & 0.000 \\
\hline Capital Structure & 4,724 & -0.027 & -0.015 & 0.051 & 185 & 3.92 & -0.026 & -0.015 & 0.035 & 4,539 & -0.027 & -0.015 & 0.052 & 0.883 & 0.958 \\
\hline Restructuring & 7,318 & -0.031 & -0.014 & 0.073 & 198 & 2.71 & -0.023 & -0.014 & 0.023 & 7,120 & -0.031 & -0.014 & 0.074 & 0.000 & 0.730 \\
\hline Ownership & 10,189 & -0.025 & -0.014 & 0.040 & 415 & 4.07 & -0.021 & -0.012 & 0.028 & 9,774 & -0.026 & -0.014 & 0.041 & 0.005 & 0.011 \\
\hline Board Changes & 1,763 & -0.035 & -0.016 & 0.069 & 63 & 3.57 & -0.021 & -0.015 & 0.022 & 1,700 & -0.035 & -0.016 & 0.070 & 0.000 & 0.422 \\
\hline General Business Info & 3,316 & -0.047 & -0.023 & 0.102 & 102 & 3.08 & -0.040 & -0.021 & 0.080 & 3,214 & -0.047 & -0.023 & 0.102 & 0.387 & 0.635 \\
\hline Miscellaneous & 12,112 & -0.033 & -0.015 & 0.076 & 357 & 2.95 & -0.028 & -0.015 & 0.034 & 11,755 & -0.033 & -0.015 & 0.077 & 0.003 & 0.542 \\
\hline
\end{tabular}

Notes: This table presents descriptive statistics of CAR News in the samples of Good News and Bad News. Good News (Bad News) is an announcement that yields nonnegative (negative) CAR News. In the sample of Good News (Bad News), an announcement is associated with insider trading if there is a positive net amount of shares bought (sold) within 30 calendar days before the announcement (News Preceded by Insider Trading). The number of observations in the All category is not equal to the sum of observation in individual categories because in the All category multiple announcements made by a firm on the same day are treated as one observation to avoid multiple counting of CARs. Differences between News Preceded by Insider Trading and News without Insider Trading are presented using T-test for differences in means and Wilcoxon Two-Sample Test for differences in medians. The sample includes all regulatory news announcements by U.K. listed companies published in the Regulatory News Service (RNS) between January 1999 and December 2002. See, Appendix A for a list of examples of news items included in each specific category. 
Table 3. Determinants of Insider Trading around News Announcements

Panel A.

OLS with Firm FE:

Panel B.

Logit with Firm FE:

the amount of net buying before good news (net selling before bad news) probability of positive net buying before good news (net selling before bad news)

\begin{tabular}{|c|c|c|c|c|c|c|c|c|c|c|c|c|c|c|c|c|}
\hline \multirow[b]{2}{*}{ Constant } & \multicolumn{4}{|c|}{ Good News } & \multicolumn{4}{|c|}{ Bad News } & \multicolumn{4}{|c|}{ Good News } & \multicolumn{4}{|c|}{ Bad News } \\
\hline & $\begin{array}{c}0.043 \\
(0.356)\end{array}$ & $\begin{array}{l}-0.043 \\
(0.606)\end{array}$ & $\begin{array}{c}0.043 \\
(0.356)\end{array}$ & $\begin{array}{l}-0.044 \\
(0.600)\end{array}$ & $\begin{array}{l}-0.080^{\mathrm{b}} \\
(0.024)\end{array}$ & $\begin{array}{l}-0.043 \\
(0.458)\end{array}$ & $\begin{array}{l}-0.080^{\mathrm{b}} \\
(0.025)\end{array}$ & $\begin{array}{l}-0.042 \\
(0.465)\end{array}$ & & & & & & & & \\
\hline LnSize & $\begin{array}{l}-0.009 \\
(0.255)\end{array}$ & $\begin{array}{l}-0.012 \\
(0.396)\end{array}$ & $\begin{array}{l}-0.009 \\
(0.255)\end{array}$ & $\begin{array}{l}-0.012 \\
(0.394)\end{array}$ & $\begin{array}{l}0.016^{\mathrm{b}} \\
(0.013)\end{array}$ & $\begin{array}{l}0.029^{\mathrm{a}} \\
(0.000)\end{array}$ & $\begin{array}{l}0.016^{\mathrm{b}} \\
(0.013)\end{array}$ & $\begin{array}{r}0.029^{\mathrm{b}} \\
(0.000)\end{array}$ & $\begin{array}{l}-0.128 \\
(0.119)\end{array}$ & $\begin{array}{l}-0.161 \\
(0.106)\end{array}$ & $\begin{array}{l}-0.124 \\
(0.137)\end{array}$ & $\begin{array}{l}-0.154 \\
(0.125)\end{array}$ & $\begin{array}{r}0.905^{\mathrm{a}} \\
(0.000)\end{array}$ & $\begin{array}{r}0.958^{\mathrm{a}} \\
(0.000)\end{array}$ & $\begin{array}{r}0.916^{\mathrm{a}} \\
(0.000)\end{array}$ & $\begin{array}{r}0.972^{\mathrm{a}} \\
(0.000)\end{array}$ \\
\hline Market-to-Book & $\begin{array}{l}-0.000 \\
(0.559)\end{array}$ & $\begin{array}{l}0.000 \\
(0.897)\end{array}$ & $\begin{array}{l}-0.000 \\
(0.558)\end{array}$ & $\begin{array}{c}0.000 \\
(0.898)\end{array}$ & $\begin{array}{l}-0.000 \\
(0.564)\end{array}$ & $\begin{array}{l}-0.001 \\
(0.483)\end{array}$ & $\begin{array}{l}-0.000 \\
(0.563)\end{array}$ & $\begin{array}{l}-0.001 \\
(0.484)\end{array}$ & $\begin{array}{l}-0.001 \\
(0.690)\end{array}$ & $\begin{array}{l}-0.000 \\
(0.640)\end{array}$ & $\begin{array}{l}-0.001 \\
(0.722)\end{array}$ & $\begin{array}{l}-0.000 \\
(0.659)\end{array}$ & $\begin{array}{c}0.002 \\
(0.541)\end{array}$ & $\begin{array}{c}0.004 \\
(0.449)\end{array}$ & $\begin{array}{c}0.002 \\
(0.587)\end{array}$ & $\begin{array}{c}0.004 \\
(0.511)\end{array}$ \\
\hline Past Return & $\begin{array}{l}-0.016^{\mathrm{a}} \\
(0.002)\end{array}$ & $\begin{array}{l}-0.011^{\mathrm{a}} \\
(0.009)\end{array}$ & $\begin{array}{l}-0.017^{\mathrm{a}} \\
(0.002)\end{array}$ & $\begin{array}{l}-0.011^{\mathrm{a}} \\
(0.008)\end{array}$ & $\begin{array}{c}0.012 \\
(0.128)\end{array}$ & $\begin{array}{l}0.011 \\
(0.105)\end{array}$ & $\begin{array}{l}0.012 \\
(0.129)\end{array}$ & $\begin{array}{c}0.011 \\
(0.105)\end{array}$ & $\begin{array}{l}-0.519^{\mathrm{a}} \\
(0.001)\end{array}$ & $\begin{array}{l}-0.709^{\mathrm{a}} \\
(0.000)\end{array}$ & $\begin{array}{l}-0.517^{\mathrm{a}} \\
(0.001)\end{array}$ & $\begin{array}{l}-0.707^{\mathrm{a}} \\
(0.000)\end{array}$ & $\begin{array}{c}0.199^{\mathrm{b}} \\
(0.036)\end{array}$ & $\begin{array}{r}0.216^{\mathrm{b}} \\
(0.037)\end{array}$ & $\begin{array}{c}0.192^{\mathrm{b}} \\
(0.046)\end{array}$ & $\begin{array}{r}0.209^{\mathrm{b}} \\
(0.045)\end{array}$ \\
\hline LnGrants & & $\begin{array}{l}-0.137 \\
(0.718)\end{array}$ & & $\begin{array}{l}-0.142 \\
(0.710)\end{array}$ & & $\begin{array}{l}0.082 \\
(0.820)\end{array}$ & & $\begin{array}{c}0.092 \\
(0.800)\end{array}$ & & $\begin{array}{l}-6.916 \\
(0.430)\end{array}$ & & $\begin{array}{l}-7.074 \\
(0.418)\end{array}$ & & $\begin{array}{l}-21.217 \\
(0.213)\end{array}$ & & $\begin{array}{r}-21.288 \\
(0.209)\end{array}$ \\
\hline Board Independence & & $\begin{array}{l}0.007 \\
(0.294)\end{array}$ & & $\begin{array}{c}0.008 \\
(0.282)\end{array}$ & & $\begin{array}{l}-0.009 \\
(0.237)\end{array}$ & & $\begin{array}{l}-0.009 \\
(0.240)\end{array}$ & & $\begin{array}{r}0.063 \\
(0.711)\end{array}$ & & $\begin{array}{c}0.071 \\
(0.681)\end{array}$ & & $\begin{array}{l}-0.191 \\
(0.398)\end{array}$ & & $\begin{array}{l}-0.207 \\
(0.366)\end{array}$ \\
\hline $\begin{array}{l}\mathrm{CEO} / \text { Chairman } \\
\text { Duality }\end{array}$ & & $\begin{array}{l}0.006 \\
(0.168)\end{array}$ & & $\begin{array}{c}0.006 \\
(0.164)\end{array}$ & & $\begin{array}{l}-0.007 \\
(0.272)\end{array}$ & & $\begin{array}{l}-0.007 \\
(0.276)\end{array}$ & & $\begin{array}{r}0.056 \\
(0.748)\end{array}$ & & $\begin{array}{c}0.067 \\
(0.704)\end{array}$ & & $\begin{array}{l}-0.470 \\
(0.189)\end{array}$ & & $\begin{array}{l}-0.469 \\
(0.196)\end{array}$ \\
\hline LnBoard Size & & $\begin{array}{l}0.045^{\mathrm{c}} \\
(0.054)\end{array}$ & & $\begin{array}{c}0.045^{\mathrm{c}} \\
(0.051)\end{array}$ & & $\begin{array}{l}-0.054^{\mathrm{c}} \\
(0.091)\end{array}$ & & $\begin{array}{l}-0.054^{\mathrm{c}} \\
(0.092)\end{array}$ & & $\begin{array}{r}0.670^{\mathrm{c}} \\
(0.082)\end{array}$ & & $\begin{array}{c}0.692^{\mathrm{c}} \\
(0.074)\end{array}$ & & $\begin{array}{c}0.643 \\
(0.374)\end{array}$ & & $\begin{array}{c}0.624 \\
(0.396)\end{array}$ \\
\hline $\mid$ CAR $\mid$ News & $\begin{array}{r}0.214^{\mathrm{a}} \\
(0.002)\end{array}$ & $\begin{array}{l}0.366^{\mathrm{a}} \\
(0.005)\end{array}$ & & & $\begin{array}{l}-0.044 \\
(0.204)\end{array}$ & $\begin{array}{l}-0.048 \\
(0.424)\end{array}$ & & & $\begin{array}{l}-0.095 \\
(0.882)\end{array}$ & $\begin{array}{l}-0.485 \\
(0.518)\end{array}$ & & & $\begin{array}{l}-5.490^{\mathrm{a}} \\
(0.000)\end{array}$ & $\begin{array}{l}-4.941^{\mathrm{a}} \\
(0.001)\end{array}$ & & \\
\hline $\mathrm{CAR}^{2}$ News & $\begin{array}{c}0.025 \\
(0.828)\end{array}$ & $\begin{array}{l}-0.336^{c} \\
(0.063)\end{array}$ & & & $\begin{array}{r}0.038^{\mathrm{c}} \\
(0.069)\end{array}$ & $\begin{array}{l}0.107^{\mathrm{c}} \\
(0.063)\end{array}$ & & & $\begin{array}{l}-0.185 \\
(0.864)\end{array}$ & $\begin{array}{c}0.228 \\
(0.896)\end{array}$ & & & $\begin{array}{r}3.248^{\mathrm{a}} \\
(0.000)\end{array}$ & $\begin{array}{r}4.260^{\mathrm{a}} \\
(0.000)\end{array}$ & & \\
\hline $\mid$ CAR $\mid$ Banned & & & $\begin{array}{l}-0.027 \\
(0.735)\end{array}$ & $\begin{array}{l}-0.031 \\
(0.836)\end{array}$ & & & $\begin{array}{l}-0.098^{\mathrm{b}} \\
(0.020)\end{array}$ & $\begin{array}{r}-0.058 \\
(0.390)\end{array}$ & & & $\begin{array}{c}-26.909^{\mathrm{a}} \\
(0.000)\end{array}$ & $\begin{array}{r}-29.737^{\mathrm{a}} \\
(0.000)\end{array}$ & & & $\begin{array}{l}-166.838^{\mathrm{a}} \\
(0.002)\end{array}$ & $\begin{array}{r}-166.929^{\mathrm{a}} \\
(0.007)\end{array}$ \\
\hline $\mathrm{CAR}^{2}$ Banned & & & $\begin{array}{c}0.086 \\
(0.663)\end{array}$ & $\begin{array}{l}-0.266 \\
(0.590)\end{array}$ & & & $\begin{array}{c}0.142^{\mathrm{a}} \\
(0.002)\end{array}$ & $\begin{array}{r}0.075 \\
(0.330)\end{array}$ & & & $\begin{array}{r}29.505^{\mathrm{a}} \\
(0.000)\end{array}$ & $\begin{array}{r}65.047^{\mathrm{a}} \\
(0.000)\end{array}$ & & & $\begin{array}{l}98.028^{\mathrm{a}} \\
(0.003)\end{array}$ & $\begin{array}{r}96.593^{\mathrm{b}} \\
(0.011)\end{array}$ \\
\hline $\mid$ CAR $\mid$ Not Banned & & & $\begin{array}{r}0.200^{\mathrm{a}} \\
(0.001)\end{array}$ & $\begin{array}{r}0.375^{\mathrm{a}} \\
(0.004)\end{array}$ & & & $\begin{array}{l}-0.043 \\
(0.206)\end{array}$ & $\begin{array}{l}-0.052 \\
(0.419)\end{array}$ & & & $\begin{array}{c}0.926 \\
(0.154)\end{array}$ & $\begin{array}{c}0.704 \\
(0.363)\end{array}$ & & & $\begin{array}{l}-4.313^{\mathrm{a}} \\
(0.001)\end{array}$ & $\begin{array}{l}-3.862^{\mathrm{b}} \\
(0.017)\end{array}$ \\
\hline $\mathrm{CAR}^{2}$ Not Banned & & & $\begin{array}{c}0.023 \\
(0.842)\end{array}$ & $\begin{array}{l}-0.331^{\mathrm{c}} \\
(0.061)\end{array}$ & & & $\begin{array}{l}0.034^{\mathrm{c}} \\
(0.094)\end{array}$ & $\begin{array}{r}0.101 \\
(0.140)\end{array}$ & & & $\begin{array}{l}-1.471 \\
(0.233)\end{array}$ & $\begin{array}{l}-1.381 \\
(0.459)\end{array}$ & & & $\begin{array}{r}2.650^{\mathrm{a}} \\
(0.000)\end{array}$ & $\begin{array}{r}3.931^{\mathrm{b}} \\
(0.041)\end{array}$ \\
\hline $\mathrm{N}$ & 39,617 & 27,735 & 39,617 & 27,735 & 38,634 & 27,459 & 38,634 & 27,459 & 30,966 & 24,081 & 30,966 & 24,081 & 17,519 & 14,113 & 17,519 & 14,113 \\
\hline $\mathrm{R}^{2} /$ Pseudo $\mathrm{R}^{2}$ & 0.001 & 0.002 & 0.001 & 0.002 & 0.002 & 0.000 & 0.000 & 0.000 & 0.008 & 0.012 & 0.014 & 0.018 & 0.038 & 0.037 & 0.050 & 0.048 \\
\hline F-test / Wald Chi ${ }^{2}$ & $6.21^{\mathrm{a}}$ & $2.93^{\mathrm{a}}$ & $4.96^{\mathrm{a}}$ & $2.96^{\mathrm{a}}$ & $3.82^{\mathrm{a}}$ & $3.49^{\mathrm{a}}$ & $4.18^{\mathrm{a}}$ & $4.28^{\mathrm{a}}$ & $29.41^{\mathrm{a}}$ & $56.25^{\mathrm{a}}$ & $68.87^{\mathrm{a}}$ & $102.85^{\mathrm{a}}$ & $63.38^{\mathrm{a}}$ & $50.24^{\mathrm{a}}$ & $155.25^{\mathrm{a}}$ & $157.60^{\mathrm{a}}$ \\
\hline
\end{tabular}


Notes: This table presents estimated coefficients of the OLS and logit regressions with firm fixed effects (Firm FE) to explain insider stock buying (selling) within 30 calendar days before Good News (Bad News). Good News (Bad News) is an announcement that yields non-negative (negative) CAR News. In the sample of Good News (Bad News) announcements the dependent variable in the OLS regressions is defined as net buying (net selling) and is calculated as the number of shares bought (sold) less the number of shares sold (bought) by insiders over 30 days before the news announcement, scaled by the number of shares outstanding, and multiplied by 100 . In the logit regressions the dependent variable equals one for news preceded by positive net buying (net selling) and zero otherwise. Standard errors of the coefficients are adjusted for clustering at the firm level. P-values of the coefficients are reported in parentheses. Additional regression diagnostics F-test and Wald Chi ${ }^{2}$ are reported for OLS and logit regressions, respectively. ${ }^{\mathrm{a}, \mathrm{b}, \mathrm{c}}$ denote significance at the $0.01,0.05$ and 0.1 level, respectively. The sample includes all regulatory news announcements by U.K. listed companies published in the Regulatory News Service (RNS) between January 1999 and December 2002. See, Appendix B for detailed definitions of the variables. 
Table 4. Determinants of Insider Trading around Different Categories of News Announcements

\begin{tabular}{|c|c|c|c|c|}
\hline & \multicolumn{2}{|c|}{$\begin{array}{c}\text { Panel } A \text {. } \\
\text { OLS with Firm FE: } \\
\text { the amount of net buying before good } \\
\text { news (net selling before bad news) }\end{array}$} & \multicolumn{2}{|c|}{$\begin{array}{c}\text { Panel } B \text {. } \\
\text { Logit with Firm FE: probability of } \\
\text { positive net buying before good news } \\
\text { (net selling before bad news) }\end{array}$} \\
\hline & Good News & Bad News & Good News & Bad News \\
\hline Constant & $\begin{array}{c}0.048 \\
(0.292)\end{array}$ & $\begin{array}{l}-0.083^{b} \\
(0.022)\end{array}$ & & \\
\hline LnSize & $\begin{array}{l}-0.010 \\
(0.212)\end{array}$ & $\begin{array}{c}0.016^{\mathrm{b}} \\
(0.012)\end{array}$ & $\begin{array}{l}-0.119 \\
(0.145)\end{array}$ & $\begin{array}{c}0.918^{\mathrm{a}} \\
(0.000)\end{array}$ \\
\hline Market-to-Book & $\begin{array}{l}-0.000 \\
(0.588)\end{array}$ & $\begin{array}{l}-0.000 \\
(0.565)\end{array}$ & $\begin{array}{l}-0.001 \\
(0.725)\end{array}$ & $\begin{array}{c}0.002 \\
(0.621)\end{array}$ \\
\hline Past Return & $\begin{array}{l}-0.016^{\mathrm{a}} \\
(0.002)\end{array}$ & $\begin{array}{c}0.011 \\
(0.139)\end{array}$ & $\begin{array}{l}-0.507^{\mathrm{a}} \\
(0.001)\end{array}$ & $\begin{array}{c}0.194^{\mathrm{b}} \\
(0.049)\end{array}$ \\
\hline |CAR| Earnings & $\begin{array}{l}-0.045 \\
(0.546)\end{array}$ & $\begin{array}{l}-0.130^{c} \\
(0.068)\end{array}$ & $\begin{array}{r}-23.541^{\mathrm{a}} \\
(0.000)\end{array}$ & $\begin{array}{r}-159.088^{\mathrm{a}} \\
(0.003)\end{array}$ \\
\hline $\mathrm{CAR}^{2}$ Earnings & $\begin{array}{c}0.114 \\
(0.565)\end{array}$ & $\begin{array}{c}0.237^{\mathrm{c}} \\
(0.073)\end{array}$ & $\begin{array}{c}25.766^{\mathrm{a}} \\
(0.000)\end{array}$ & $\begin{array}{c}55.878 \\
(0.216)\end{array}$ \\
\hline$|\mathrm{CAR}|$ Other Results and Div & $\begin{array}{c}0.268^{b} \\
(0.014)\end{array}$ & $\begin{array}{l}-0.053 \\
(0.302)\end{array}$ & $\begin{array}{l}-6.604^{a} \\
(0.000)\end{array}$ & $\begin{array}{l}-9.000^{a} \\
(0.001)\end{array}$ \\
\hline $\mathrm{CAR}^{2}$ Other Results and Div & $\begin{array}{l}-0.574^{\mathrm{a}} \\
(0.009)\end{array}$ & $\begin{array}{c}0.031 \\
(0.425)\end{array}$ & $\begin{array}{c}11.868^{\mathrm{a}} \\
(0.000)\end{array}$ & $\begin{array}{c}7.353^{b} \\
(0.017)\end{array}$ \\
\hline$|\mathrm{CAR}|$ Capital Structure & $\begin{array}{l}-0.189^{b} \\
(0.016)\end{array}$ & $\begin{array}{c}0.380 \\
(0.199)\end{array}$ & $\begin{array}{c}6.118^{a} \\
(0.002)\end{array}$ & $\begin{array}{l}-1.972 \\
(0.653)\end{array}$ \\
\hline $\mathrm{CAR}^{2}$ Capital Structure & $\begin{array}{c}1.175^{\mathrm{a}} \\
(0.000)\end{array}$ & $\begin{array}{l}-0.351 \\
(0.243)\end{array}$ & $\begin{array}{l}-7.544 \\
(0.331)\end{array}$ & $\begin{array}{c}38.720 \\
(0.207)\end{array}$ \\
\hline |CAR| Restructuring & $\begin{array}{c}0.339^{b} \\
(0.022)\end{array}$ & $\begin{array}{l}-0.042 \\
(0.258)\end{array}$ & $\begin{array}{l}-3.001^{b} \\
(0.031)\end{array}$ & $\begin{array}{c}1.003 \\
(0.888)\end{array}$ \\
\hline $\mathrm{CAR}^{2}$ Restructuring & $\begin{array}{l}-0.558^{\mathrm{a}} \\
(0.001)\end{array}$ & $\begin{array}{c}0.016 \\
(0.506)\end{array}$ & $\begin{array}{c}4.346 \\
(0.215)\end{array}$ & $\begin{array}{r}-83.434^{\mathrm{c}} \\
(0.086)\end{array}$ \\
\hline$|\mathrm{CAR}|$ Ownership & $\begin{array}{c}0.255^{\mathrm{c}} \\
(0.077)\end{array}$ & $\begin{array}{l}-0.059 \\
(0.534)\end{array}$ & $\begin{array}{c}5.369^{\mathrm{a}} \\
(0.000)\end{array}$ & $\begin{array}{c}2.419 \\
(0.466)\end{array}$ \\
\hline $\mathrm{CAR}^{2}$ Ownership & $\begin{array}{c}0.075 \\
(0.683)\end{array}$ & $\begin{array}{c}0.080 \\
(0.447)\end{array}$ & $\begin{array}{l}-7.416^{b} \\
(0.046)\end{array}$ & $\begin{array}{r}-21.319 \\
(0.378)\end{array}$ \\
\hline |CAR| Board Changes & $\begin{array}{l}-0.096 \\
(0.713)\end{array}$ & $\begin{array}{c}0.011 \\
(0.912)\end{array}$ & $\begin{array}{c}1.482 \\
(0.564)\end{array}$ & $\begin{array}{c}9.355 \\
(0.367)\end{array}$ \\
\hline CAR $^{2}$ Board Changes & $\begin{array}{c}0.008 \\
(0.993)\end{array}$ & $\begin{array}{l}-0.001 \\
(0.989)\end{array}$ & $\begin{array}{r}-15.360 \\
(0.165)\end{array}$ & $\begin{array}{r}-174.520 \\
(0.245)\end{array}$ \\
\hline$|\mathrm{CAR}|$ General Business Info & $\begin{array}{c}0.134^{\mathrm{c}} \\
(0.070)\end{array}$ & $\begin{array}{l}-0.098 \\
(0.106)\end{array}$ & $\begin{array}{c}1.043 \\
(0.365)\end{array}$ & $\begin{array}{l}-5.059^{c} \\
(0.097)\end{array}$ \\
\hline $\mathrm{CAR}^{2}$ General Business Info & $\begin{array}{l}-0.303^{c} \\
(0.051)\end{array}$ & $\begin{array}{c}0.083^{c} \\
(0.089)\end{array}$ & $\begin{array}{l}-1.212 \\
(0.589)\end{array}$ & $\begin{array}{c}6.939^{b} \\
(0.015)\end{array}$ \\
\hline$|\mathrm{CAR}|$ Miscellaneous & $\begin{array}{c}0.141 \\
(0.214)\end{array}$ & $\begin{array}{c}0.035 \\
(0.462)\end{array}$ & $\begin{array}{l}-1.477 \\
(0.234)\end{array}$ & $\begin{array}{c}0.015 \\
(0.997)\end{array}$ \\
\hline $\mathrm{CAR}^{2}$ Miscellaneous & $\begin{array}{c}0.014 \\
(0.859)\end{array}$ & $\begin{array}{l}-0.010 \\
(0.719)\end{array}$ & $\begin{array}{l}-0.166 \\
(0.962)\end{array}$ & $\begin{array}{l}-8.155 \\
(0.673)\end{array}$ \\
\hline $\mathrm{N}$ & 39,617 & 38,634 & 30,966 & 17,519 \\
\hline $\mathrm{R}^{2} /$ Pseudo $\mathrm{R}^{2}$ & 0.001 & 0.004 & 0.019 & 0.054 \\
\hline F-test / Wald Chi ${ }^{2}$ & $15.08^{\mathrm{a}}$ & $2.11^{\mathrm{a}}$ & $197.14^{\mathrm{a}}$ & $214.10^{\mathrm{a}}$ \\
\hline
\end{tabular}

Notes: This table presents estimated coefficients of the OLS and logit regressions with firm fixed effects (Firm FE) to explain insider stock buying (selling) within 30 calendar days before Good News (Bad News) across different categories of the news (Earnings, Other Results and Dividends, Capital Structure, Restructuring, 
Ownership, Board Changes, General Business Information and Miscellaneous). Good News (Bad News) is an announcement that yields non-negative (negative) CAR News. In the sample of Good News (Bad News) announcements the dependent variable in the OLS regressions is defined as net buying (net selling) and is calculated as the number of shares bought (sold) less the number of shares sold (bought) by insiders over 30 days before the news announcement, scaled by the number of shares outstanding, and multiplied by 100. In the logit regressions the dependent variable equals one for news preceded by positive net buying (net selling) and zero otherwise. $|C A R|$ Earnings $(|C A R|$ Other Results and Div, $|C A R|$ Capital Structure, $|C A R|$ Restructuring, $|C A R|$ Ownership, $|C A R|$ Board Changes, $|C A R|$ General Business Info, $|C A R|$ Miscellaneous) is the absolute value of cumulative abnormal return over days 0 and +1 relative to the news announcement in a group of Earnings (Other Results and Div, Capital Structure, Restructuring, Ownership, Board Changes, General Business Info, and Miscellaneous). Standard errors of the coefficients are adjusted for clustering at the firm level. P-values of the coefficients are reported in parentheses. Additional regression diagnostics F-test and $\mathrm{Wald} \mathrm{Chi}^{2}$ are reported for OLS and logit regressions, respectively. ${ }^{\mathrm{a}, \mathrm{b}, \mathrm{c}}$ denote significance at the $0.01,0.05$ and 0.1 level, respectively. The sample includes news announcements by U.K. listed companies published in the Regulatory News Service (RNS) between January 1999 and December 2002. See, Appendix A for a list of examples of news items included in each specific category and Appendix B for definitions of the variables. 
Table 5. The Effect of New Regulations on the Determinants of Insider Trading

\begin{tabular}{|c|c|c|c|c|c|c|c|c|}
\hline \multirow[b]{3}{*}{ Constant } & \multicolumn{4}{|c|}{$\begin{array}{c}\text { Panel } A \text {. } \\
\text { OLS with Firm FE: } \\
\text { the amount of net buying before good } \\
\text { news (net selling before bad news) }\end{array}$} & \multicolumn{4}{|c|}{$\begin{array}{c}\text { Panel } B \text {. } \\
\text { Logit with Firm FE: } \\
\text { probability of positive net buying before good } \\
\text { news (net selling before bad news) }\end{array}$} \\
\hline & \multicolumn{2}{|c|}{ Good News } & \multicolumn{2}{|c|}{ Bad News } & \multicolumn{2}{|c|}{ Good News } & \multicolumn{2}{|c|}{ Bad News } \\
\hline & $\begin{array}{c}0.030 \\
(0.526)\end{array}$ & $\begin{array}{c}0.029 \\
(0.533)\end{array}$ & $\begin{array}{l}-0.087^{b} \\
(0.040)\end{array}$ & $\begin{array}{l}-0.087^{\mathrm{b}} \\
(0.041)\end{array}$ & & & & \\
\hline LnSize & $\begin{array}{l}-0.007 \\
(0.414)\end{array}$ & $\begin{array}{l}-0.007 \\
(0.421)\end{array}$ & $\begin{array}{c}0.016^{\mathrm{b}} \\
(0.023)\end{array}$ & $\begin{array}{c}0.016^{\mathrm{b}} \\
(0.023)\end{array}$ & $\begin{array}{l}-0.124 \\
(0.130)\end{array}$ & $\begin{array}{l}-0.116 \\
(0.160)\end{array}$ & $\begin{array}{c}0.908^{\mathrm{a}} \\
(0.000)\end{array}$ & $\begin{array}{r}0.918^{\mathrm{a}} \\
(0.000)\end{array}$ \\
\hline Market-to-Book & $\begin{array}{l}-0.000 \\
(0.575)\end{array}$ & $\begin{array}{l}-0.000 \\
(0.578)\end{array}$ & $\begin{array}{l}-0.000 \\
(0.564)\end{array}$ & $\begin{array}{l}-0.000 \\
(0.563)\end{array}$ & $\begin{array}{l}-0.001 \\
(0.703)\end{array}$ & $\begin{array}{l}-0.001 \\
(0.737)\end{array}$ & $\begin{array}{c}0.002 \\
(0.555)\end{array}$ & $\begin{array}{c}0.002 \\
(0.606)\end{array}$ \\
\hline Past Return & $\begin{array}{l}-0.016^{\mathrm{a}} \\
(0.003)\end{array}$ & $\begin{array}{l}-0.016^{\mathrm{a}} \\
(0.002)\end{array}$ & $\begin{array}{c}0.012 \\
(0.125)\end{array}$ & $\begin{array}{c}0.012 \\
(0.127)\end{array}$ & $\begin{array}{l}-0.519^{\mathrm{a}} \\
(0.001)\end{array}$ & $\begin{array}{l}-0.518^{\mathrm{a}} \\
(0.001)\end{array}$ & $\begin{array}{c}0.199^{b} \\
(0.036)\end{array}$ & $\begin{array}{r}0.192^{\mathrm{b}} \\
(0.046)\end{array}$ \\
\hline POST & $\begin{array}{l}-0.007 \\
(0.435)\end{array}$ & $\begin{array}{l}-0.008 \\
(0.413)\end{array}$ & $\begin{array}{c}0.006 \\
(0.585)\end{array}$ & $\begin{array}{c}0.006 \\
(0.578)\end{array}$ & $\begin{array}{l}-0.008 \\
(0.925)\end{array}$ & $\begin{array}{l}-0.013 \\
(0.884)\end{array}$ & $\begin{array}{l}-0.069 \\
(0.616)\end{array}$ & $\begin{array}{l}-0.078 \\
(0.574)\end{array}$ \\
\hline $\mid$ CAR $\mid$ News & $\begin{array}{c}0.134^{\mathrm{c}} \\
(0.058)\end{array}$ & & $\begin{array}{l}-0.042 \\
(0.209)\end{array}$ & & $\begin{array}{l}-0.326 \\
(0.674)\end{array}$ & & $\begin{array}{l}-6.981^{\mathrm{a}} \\
(0.000)\end{array}$ & \\
\hline $\mathrm{CAR}^{2}$ News & $\begin{array}{c}0.109 \\
(0.454)\end{array}$ & & $\begin{array}{c}0.032^{\mathrm{c}} \\
(0.095)\end{array}$ & & $\begin{array}{c}0.592 \\
(0.616)\end{array}$ & & $\begin{array}{c}9.430^{b} \\
(0.016)\end{array}$ & \\
\hline $\mid$ CAR $\mid$ News $\times$ POST & $\begin{array}{r}0.485^{\mathrm{c}} \\
(0.085)\end{array}$ & & $\begin{array}{l}-0.016 \\
(0.849)\end{array}$ & & $\begin{array}{c}1.200 \\
(0.421)\end{array}$ & & $\begin{array}{c}1.619 \\
(0.623)\end{array}$ & \\
\hline $\mathrm{CAR}^{2}$ News $\times$ POST & $\begin{array}{l}-0.777^{b} \\
(0.045)\end{array}$ & & $\begin{array}{c}0.029 \\
(0.625)\end{array}$ & & $\begin{array}{l}-3.881 \\
(0.213)\end{array}$ & & $\begin{array}{l}-6.712^{c} \\
(0.099)\end{array}$ & \\
\hline $\mid$ CAR $\mid$ Banned & & $\begin{array}{c}0.021 \\
(0.820)\end{array}$ & & $\begin{array}{l}-0.130^{\mathrm{a}} \\
(0.005)\end{array}$ & & $\begin{array}{r}-22.621^{\mathrm{a}} \\
(0.000)\end{array}$ & & $\begin{array}{r}-202.884^{b} \\
(0.010)\end{array}$ \\
\hline $\mathrm{CAR}^{2}$ Banned & & $\begin{array}{c}0.061 \\
(0.768)\end{array}$ & & $\begin{array}{c}0.181^{\mathrm{b}} \\
(0.010)\end{array}$ & & $\begin{array}{c}24.665^{\mathrm{a}} \\
(0.000)\end{array}$ & & $\begin{array}{r}234.177^{b} \\
(0.017)\end{array}$ \\
\hline $\mid$ CAR $\mid$ Banned $\times$ POST & & $\begin{array}{c}0.052 \\
(0.743)\end{array}$ & & $\begin{array}{c}0.093 \\
(0.141)\end{array}$ & & $\begin{array}{c}-32.152 \\
(0.103)\end{array}$ & & $\begin{array}{c}102.071 \\
(0.536)\end{array}$ \\
\hline $\mathrm{CAR}^{2}$ Banned $\times$ POST & & $\begin{array}{l}-0.636 \\
(0.220)\end{array}$ & & $\begin{array}{l}-0.097 \\
(0.205)\end{array}$ & & $\begin{array}{c}85.938^{\mathrm{b}} \\
(0.038)\end{array}$ & & $\begin{array}{r}-546.743 \\
(0.873)\end{array}$ \\
\hline$|\mathrm{CAR}|$ Not Banned & & $\begin{array}{c}0.132^{\mathrm{c}} \\
(0.057)\end{array}$ & & $\begin{array}{l}-0.036 \\
(0.265)\end{array}$ & & $\begin{array}{c}0.482 \\
(0.529)\end{array}$ & & $\begin{array}{l}-5.587^{\mathrm{a}} \\
(0.002)\end{array}$ \\
\hline $\mathrm{CAR}^{2}$ Not Banned & & $\begin{array}{c}0.112 \\
(0.441)\end{array}$ & & $\begin{array}{c}0.028 \\
(0.121)\end{array}$ & & $\begin{array}{l}-0.241 \\
(0.846)\end{array}$ & & $\begin{array}{l}7.671^{\mathrm{c}} \\
(0.064)\end{array}$ \\
\hline$|\mathrm{CAR}|$ Not Banned $\times$ POST & & $\begin{array}{c}0.528^{\mathrm{c}} \\
(0.069)\end{array}$ & & $\begin{array}{l}-0.027 \\
(0.761)\end{array}$ & & $\begin{array}{c}1.985 \\
(0.208)\end{array}$ & & $\begin{array}{l}1.628 \\
(0.606)\end{array}$ \\
\hline $\mathrm{CAR}^{2}$ Not Banned $\times$ POST & & $\begin{array}{l}-0.820^{\mathrm{b}} \\
(0.038)\end{array}$ & & $\begin{array}{c}0.030 \\
(0.657)\end{array}$ & & $\begin{array}{l}-5.847 \\
(0.110)\end{array}$ & & $\begin{array}{l}-5.770 \\
(0.187)\end{array}$ \\
\hline $\mathrm{N}$ & 39,617 & 39,617 & 38,634 & 38,634 & 30,966 & 30,966 & 17,519 & 17,519 \\
\hline $\mathrm{R}^{2} /$ Pseudo $\mathrm{R}^{2}$ & 0.001 & 0.001 & 0.000 & 0.000 & 0.008 & 0.014 & 0.039 & 0.050 \\
\hline F-test / Wald Chi ${ }^{2}$ & $4.11^{\mathrm{a}}$ & $3.15^{\mathrm{a}}$ & $2.57^{\mathrm{a}}$ & $3.84^{\mathrm{a}}$ & $30.39^{\mathrm{a}}$ & $70.79^{\mathrm{a}}$ & $71.69^{\mathrm{a}}$ & $240.32^{\mathrm{a}}$ \\
\hline
\end{tabular}

Notes: This table presents estimated coefficients of the OLS and logit regressions with firm fixed effects (Firm FE) to explain insider stock buying (selling) within 30 calendar days before Good News (Bad News). Good News (Bad News) is an announcement that yields non-negative (negative) CAR News. In the sample of Good News (Bad News) announcements the dependent variable in the OLS regressions is defined as net buying (net selling) and is calculated as the number of shares bought (sold) less the number of shares sold (bought) by insiders over 30 days before the news announcement, scaled by the number of shares outstanding, and multiplied by 100. In the logit regressions the dependent variable equals one for news preceded by positive net buying (net selling) and zero otherwise. Standard errors of the coefficients are adjusted for clustering at the firm level. P-values of the coefficients are reported in parentheses. Additional regression diagnostics F-test and Wald $\mathrm{Chi}^{2}$ are reported for OLS and logit regressions, respectively. ${ }^{\mathrm{a}, \mathrm{b}, \mathrm{c}}$ denote significance at the $0.01,0.05$ and 0.1 level, respectively. The sample includes all regulatory news announcements by U.K. listed companies published in the Regulatory News Service (RNS) between January 1999 and December 2002. See, Appendix B for detailed definitions of the variables. 
Table 6. The Effect of Reputation on Insider Trading by CEOs and Chairmen around News Announcements

\begin{tabular}{|c|c|c|c|c|}
\hline & \multicolumn{2}{|c|}{$\begin{array}{c}\text { Panel } A \text {. } \\
\text { OLS with Firm FE: } \\
\text { the amount of net buying before good news } \\
\text { (net selling before bad news) }\end{array}$} & \multicolumn{2}{|c|}{$\begin{array}{c}\text { Panel } B \text {. } \\
\text { Logit with Firm FE: } \\
\text { probability of positive net buying before good } \\
\text { news (net selling before bad news) }\end{array}$} \\
\hline & Good News & Bad News & Good News & Bad News \\
\hline \multicolumn{5}{|l|}{ CEOs } \\
\hline Constant & $\begin{array}{l}-0.021 \\
(0.779)\end{array}$ & $\begin{array}{l}-0.094^{\mathrm{a}} \\
(0.006)\end{array}$ & & \\
\hline LnSize & $\begin{array}{c}0.009 \\
(0.474)\end{array}$ & $\begin{array}{c}0.008^{\mathrm{b}} \\
(0.011)\end{array}$ & $\begin{array}{l}-0.263 \\
(0.111)\end{array}$ & $\begin{array}{r}1.689^{\mathrm{a}} \\
(0.000)\end{array}$ \\
\hline Market-to-Book & $\begin{array}{l}-0.000 \\
(0.268)\end{array}$ & $\begin{array}{c}0.000 \\
(0.387)\end{array}$ & $\begin{array}{l}-0.003^{b} \\
(0.020)\end{array}$ & $\begin{array}{r}0.017^{\mathrm{c}} \\
(0.076)\end{array}$ \\
\hline Past Return & $\begin{array}{l}-0.005^{\mathrm{c}} \\
(0.094)\end{array}$ & $\begin{array}{c}0.006 \\
(0.126)\end{array}$ & $\begin{array}{l}-0.684^{\mathrm{a}} \\
(0.000)\end{array}$ & $\begin{array}{c}0.171 \\
(0.128)\end{array}$ \\
\hline \# Boards & $\begin{array}{l}-0.003 \\
(0.197)\end{array}$ & $\begin{array}{l}-0.002 \\
(0.430)\end{array}$ & $\begin{array}{c}0.163 \\
(0.223)\end{array}$ & $\begin{array}{c}0.222 \\
(0.270)\end{array}$ \\
\hline Age & $\begin{array}{l}-0.001 \\
(0.176)\end{array}$ & $\begin{array}{c}0.001^{\mathrm{c}} \\
(0.067)\end{array}$ & $\begin{array}{c}0.002 \\
(0.884)\end{array}$ & $\begin{array}{r}0.038^{\mathrm{b}} \\
(0.037)\end{array}$ \\
\hline$|\mathrm{CAR}|$ Banned & $\begin{array}{c}0.000 \\
(0.998)\end{array}$ & $\begin{array}{l}-0.029 \\
(0.213)\end{array}$ & $\begin{array}{r}-25.419^{\mathrm{a}} \\
(0.001)\end{array}$ & $\begin{array}{c}-23,796.39^{\mathrm{a}} \\
(0.000)\end{array}$ \\
\hline $\mathrm{CAR}^{2}$ Banned & $\begin{array}{l}-0.134 \\
(0.621)\end{array}$ & $\begin{array}{r}0.052^{\mathrm{c}} \\
(0.063)\end{array}$ & $\begin{array}{c}59.244^{\mathrm{a}} \\
(0.001)\end{array}$ & $\begin{array}{l}14274.6^{\mathrm{a}} \\
(0.000)\end{array}$ \\
\hline |CAR| Not Banned & $\begin{array}{r}0.256^{\mathrm{b}} \\
(0.029)\end{array}$ & $\begin{array}{l}-0.006 \\
(0.893)\end{array}$ & $\begin{array}{r}2.690^{\mathrm{b}} \\
(0.028)\end{array}$ & $\begin{array}{r}8.506^{\mathrm{b}} \\
(0.045)\end{array}$ \\
\hline $\mathrm{CAR}^{2}$ Not Banned & $\begin{array}{l}-0.243^{c} \\
(0.088)\end{array}$ & $\begin{array}{c}0.012 \\
(0.762)\end{array}$ & $\begin{array}{l}-4.187 \\
(0.177)\end{array}$ & $\begin{array}{r}-34.664^{\mathrm{c}} \\
(0.070)\end{array}$ \\
\hline $\mathrm{N}$ & 26,972 & 26,724 & 15,880 & 5,300 \\
\hline $\mathrm{R}^{2} /$ Pseudo $\mathrm{R}^{2}$ & 0.001 & 0.000 & 0.020 & 0.087 \\
\hline F-test / Wald Chi ${ }^{2}$ & 1.13 & $10.16^{\mathrm{a}}$ & $60.22^{\mathrm{a}}$ & $831.71^{\mathrm{a}}$ \\
\hline \multicolumn{5}{|l|}{ Chairmen } \\
\hline Constant & $\begin{array}{l}-0.093 \\
(0.218)\end{array}$ & $\begin{array}{c}0.033 \\
(0.370)\end{array}$ & & \\
\hline LnSize & $\begin{array}{c}0.010 \\
(0.386)\end{array}$ & $\begin{array}{c}0.003 \\
(0.109)\end{array}$ & $\begin{array}{l}-0.395^{\mathrm{a}} \\
(0.007)\end{array}$ & $\begin{array}{c}1.181^{\mathrm{a}} \\
(0.001)\end{array}$ \\
\hline Market-to-Book & $\begin{array}{c}0.000 \\
(0.205)\end{array}$ & $\begin{array}{c}0.000 \\
(0.219)\end{array}$ & $\begin{array}{l}-0.005 \\
(0.110)\end{array}$ & $\begin{array}{l}-0.005 \\
(0.636)\end{array}$ \\
\hline Past Return & $\begin{array}{l}-0.003 \\
(0.254)\end{array}$ & $\begin{array}{c}0.004 \\
(0.229)\end{array}$ & $\begin{array}{l}-0.285 \\
(0.288)\end{array}$ & $\begin{array}{c}0.124 \\
(0.257)\end{array}$ \\
\hline \# Boards & $\begin{array}{l}-0.001 \\
(0.166)\end{array}$ & $\begin{array}{c}0.000 \\
(0.489)\end{array}$ & $\begin{array}{c}0.092 \\
(0.242)\end{array}$ & $\begin{array}{l}-0.781^{\mathrm{a}} \\
(0.009)\end{array}$ \\
\hline Age & $\begin{array}{c}0.000 \\
(0.234)\end{array}$ & $\begin{array}{l}-0.001 \\
(0.169)\end{array}$ & $\begin{array}{l}-0.013 \\
(0.625)\end{array}$ & $\begin{array}{l}-0.006 \\
(0.910)\end{array}$ \\
\hline$|\mathrm{CAR}|$ Banned & $\begin{array}{l}-0.016 \\
(0.821)\end{array}$ & $\begin{array}{l}-0.018 \\
(0.379)\end{array}$ & $\begin{array}{c}-23.871 \\
(0.121)\end{array}$ & $\begin{array}{c}22.770 \\
(0.891)\end{array}$ \\
\hline $\mathrm{CAR}^{2}$ Banned & $\begin{array}{l}-0.040 \\
(0.865)\end{array}$ & $\begin{array}{l}-0.001 \\
(0.979)\end{array}$ & $\begin{array}{c}7.112 \\
(0.939)\end{array}$ & $\begin{array}{r}-4,272.25 \\
(0.407)\end{array}$ \\
\hline$|\mathrm{CAR}|$ Not Banned & $\begin{array}{c}0.217^{\mathrm{b}} \\
(0.049)\end{array}$ & $\begin{array}{l}-0.017 \\
(0.445)\end{array}$ & $\begin{array}{c}2.109 \\
(0.150)\end{array}$ & $\begin{array}{l}-0.3492 \\
(0.879)\end{array}$ \\
\hline CAR $^{2}$ Not Banned & $\begin{array}{l}-0.254^{\mathrm{c}} \\
(0.082)\end{array}$ & $\begin{array}{c}0.036 \\
(0.220)\end{array}$ & $\begin{array}{l}-7.445 \\
(0.159)\end{array}$ & $\begin{array}{c}2.640 \\
(0.254)\end{array}$ \\
\hline $\mathrm{N}$ & 27,315 & 27,023 & 13,679 & 3,885 \\
\hline $\mathrm{R}^{2} /$ Pseudo $\mathrm{R}^{2}$ & 0.000 & 0.001 & 0.016 & 0.063 \\
\hline F-test / Wald Chi ${ }^{2}$ & 1.36 & $1.83^{\mathrm{c}}$ & $53.25^{\mathrm{a}}$ & $69.62^{\mathrm{a}}$ \\
\hline
\end{tabular}


Notes: This table presents estimated coefficients of the OLS and logit regressions with firm fixed effects (Firm FE) to explain CEOs stock buying (selling) within 30 calendar days before Good News (Bad News). Good News (Bad News) is an announcement that yields non-negative (negative) CAR News. In the sample of Good News (Bad News) announcements the dependent variable in the OLS regressions is defined as net buying (net selling) and is calculated as the number of shares bought (sold) less the number of shares sold (bought) by insiders over 30 days before the news announcement, scaled by the number of shares outstanding, and multiplied by 100. In the logit regressions the dependent variable equals one for news preceded by positive net buying (net selling) and zero otherwise. Standard errors of the coefficients are adjusted for clustering at the firm level. P-values of the coefficients are reported in parentheses. Additional regression diagnostics F-test

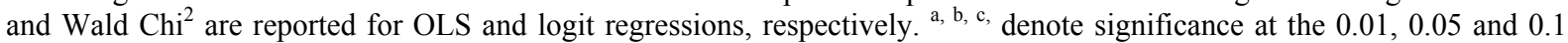
level, respectively. The sample includes all regulatory news announcements by U.K. listed companies published in the Regulatory News Service (RNS) between January 1999 and December 2002. See, Appendix B for detailed definitions of the variables. 
Table 7. Alternative Measures of the Information Content of the News

\begin{tabular}{|c|c|c|c|c|}
\hline & \multicolumn{2}{|c|}{$\begin{array}{c}\text { Panel } A \text {. } \\
\text { OLS with Firm FE: } \\
\text { the amount of net buying before good news } \\
\text { (net selling before bad news) }\end{array}$} & \multicolumn{2}{|c|}{$\begin{array}{c}\text { Pane } B \text {. } \\
\text { Logit with Firm FE: } \\
\text { probability of positive net buying before } \\
\text { good news (net selling before bad news) }\end{array}$} \\
\hline & Good News & Bad News & Good News & Bad News \\
\hline \multicolumn{5}{|l|}{$C A R[-20,+1]$} \\
\hline \multirow[t]{2}{*}{ |CAR| Banned } & $0.098^{\mathrm{c}}$ & $-0.058^{b}$ & $-13.862^{\mathrm{a}}$ & $-25.961^{b}$ \\
\hline & $(0.098)$ & $(0.018)$ & $(0.000)$ & $(0.031)$ \\
\hline \multirow[t]{2}{*}{$\mathrm{CAR}^{2}$ Banned } & $-0.106^{\mathrm{c}}$ & $0.066^{\mathrm{a}}$ & $11.760^{\mathrm{a}}$ & $17.591^{\mathrm{a}}$ \\
\hline & $(0.098)$ & $(0.003)$ & $(0.000)$ & $(6.198)$ \\
\hline \multirow[t]{2}{*}{$|\mathrm{CAR}|$ Not Banned } & 0.069 & $-0.039^{\mathrm{c}}$ & $1.333^{\mathrm{a}}$ & $1.817^{\mathrm{c}}$ \\
\hline & $(0.186)$ & $(0.080)$ & $(0.007)$ & $(0.079)$ \\
\hline \multirow[t]{2}{*}{$\mathrm{CAR}^{2}$ Not Banned } & 0.024 & 0.013 & -0.307 & $-4.735^{b}$ \\
\hline & $(0.635)$ & $(0.334)$ & $(0.590)$ & $(2.023)$ \\
\hline $\mathrm{N}$ & 40,054 & 38,197 & 40,054 & 38,197 \\
\hline $\mathrm{R}^{2} /$ Pseudo $\mathrm{R}^{2}$ & 0.002 & 0.000 & 0.018 & 0.039 \\
\hline F-test / Wald Chi ${ }^{2}$ & $3.50^{\mathrm{a}}$ & $3.33^{\mathrm{a}}$ & $118.95^{\mathrm{a}}$ & $33.87^{\mathrm{a}}$ \\
\hline \multicolumn{5}{|l|}{$C A R[-10,+1]$} \\
\hline \multirow[t]{2}{*}{ |CAR| Banned } & 0.098 & $-0.103^{\mathrm{a}}$ & $-16.891^{\mathrm{a}}$ & $-70.232^{\mathrm{a}}$ \\
\hline & $(0.162)$ & $(0.002)$ & $(0.000)$ & $(0.006)$ \\
\hline \multirow[t]{2}{*}{$\mathrm{CAR}^{2}$ Banned } & $-0.178^{c}$ & $0.145^{\mathrm{a}}$ & $15.441^{\mathrm{a}}$ & $39.696^{\mathrm{a}}$ \\
\hline & $(0.051)$ & $(0.000)$ & $(0.000)$ & $(0.005)$ \\
\hline \multirow[t]{2}{*}{$|\mathrm{CAR}|$ Not Banned } & $0.090^{\mathrm{c}}$ & -0.036 & $1.682^{\mathrm{a}}$ & $-1.431^{\mathrm{c}}$ \\
\hline & $(0.064)$ & $(0.116)$ & $(0.002)$ & $(1.82)$ \\
\hline \multirow[t]{2}{*}{ CAR $^{2}$ Not Banned } & 0.012 & 0.004 & -0.474 & 0.500 \\
\hline & $(0.837)$ & $(0.841)$ & $(0.552)$ & $(0.582)$ \\
\hline $\mathrm{N}$ & 39,875 & 38,376 & 30,401 & 16,662 \\
\hline $\mathrm{R}^{2} /$ Pseudo $\mathrm{R}^{2}$ & 0.002 & 0.000 & 0.019 & 0.045 \\
\hline F-test / Wald Chi ${ }^{2}$ & $3.36^{\mathrm{a}}$ & $4.22^{\mathrm{a}}$ & $125.87^{\mathrm{a}}$ & $50.93^{\mathrm{a}}$ \\
\hline \multicolumn{5}{|l|}{$C A R[-5,+1]$} \\
\hline \multirow[t]{2}{*}{ |CAR $\mid$ Banned } & 0.087 & $-0.081^{b}$ & $-20.693^{\mathrm{a}}$ & $-57.131^{\mathrm{a}}$ \\
\hline & $(0.138)$ & $(0.045)$ & $(0.000)$ & $(0.007)$ \\
\hline \multirow[t]{2}{*}{$\mathrm{CAR}^{2}$ Banned } & $-0.188^{\mathrm{c}}$ & $0.096^{\mathrm{c}}$ & $19.818^{\mathrm{a}}$ & $32.435^{\mathrm{a}}$ \\
\hline & $(0.067)$ & $(0.074)$ & $(0.000)$ & $(0.005)$ \\
\hline \multirow[t]{2}{*}{$|\mathrm{CAR}|$ Not Banned } & $0.117^{\mathrm{b}}$ & -0.032 & $2.123^{\mathrm{a}}$ & -0.436 \\
\hline & $(0.029)$ & $(0.167)$ & $(0.000)$ & $(0.653)$ \\
\hline \multirow[t]{2}{*}{$\mathrm{CAR}^{2}$ Not Banned } & 0.024 & 0.021 & $-1.493^{b}$ & -0.222 \\
\hline & $(0.752)$ & $(0.173)$ & $(0.045)$ & $(0.905)$ \\
\hline $\mathrm{N}$ & 39,563 & 38,598 & 30,412 & 17,355 \\
\hline $\mathrm{R}^{2} /$ Pseudo $\mathrm{R}^{2}$ & 0.001 & 0.001 & 0.015 & 0.044 \\
\hline F-test / Wald Chi ${ }^{2}$ & $3.96^{\mathrm{a}}$ & $2.91^{\mathrm{a}}$ & $107.87^{\mathrm{a}}$ & $42.81^{\mathrm{a}}$ \\
\hline
\end{tabular}

Notes: This table presents estimated coefficients of the main variables of interest of the OLS and logit regressions with firm fixed effects (Firm FE) to explain insider stock buying (selling) within 30 calendar days before Good News (Bad News). Good News (Bad News) is an announcement that yields non-negative (negative) CAR News. In the sample of Good News (Bad News) announcements the dependent variable in the OLS regressions is defined as net buying (net selling) and is calculated as the number of shares bought (sold) less the number of shares sold (bought) by insiders over 30 days before the news announcement, scaled by the number of shares outstanding, and multiplied by 100. In the logit regressions the dependent variable equals one for news preceded by positive net buying (net selling) and zero otherwise. $\mid$ CAR $\mid$ News is the absolute value of cumulative abnormal return over different windows: $[-20,+1],[-10,+1]$ and $[-5,+1]$ relative to the news announcement. Standard errors of the coefficients are adjusted for clustering at the firm level. P-values of the coefficients are

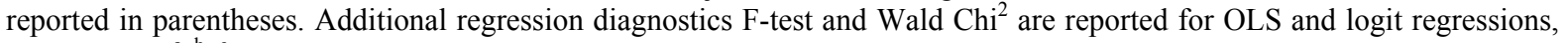
respectively. ${ }^{a, b, c}$ denote significance at the $0.01,0.05$ and 0.1 level, respectively. The sample includes all regulatory news announcements by U.K. listed companies published in the Regulatory News Service (RNS) between January 1999 and December 2002 See, Appendix B for detailed definitions of the variables. 
Figure 1. Number of insider transactions before news announcements

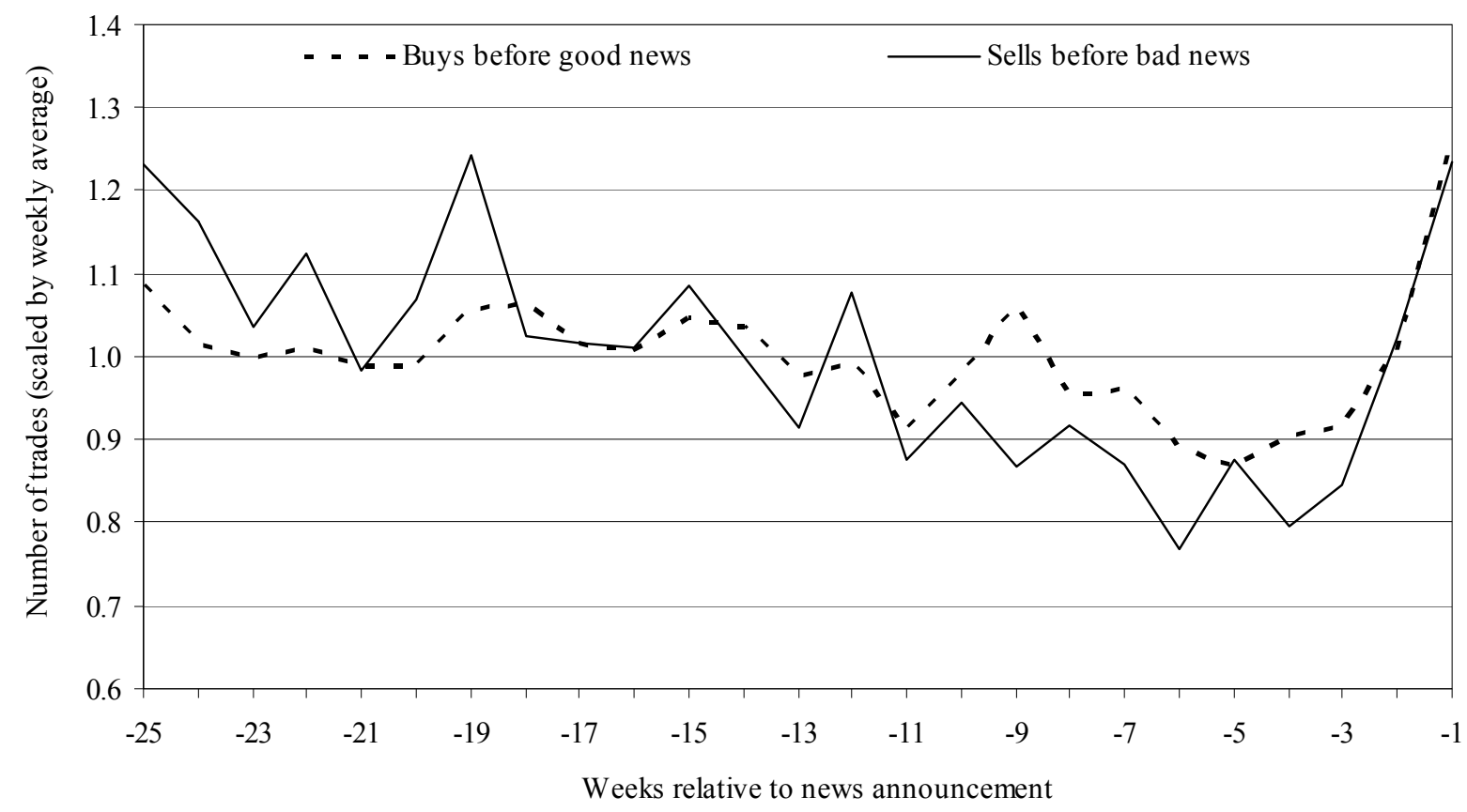

Notes: This figure presents the number of buys (sells) over 25 weeks before good (bad) news announcements. The number of trades in each week is scaled by the average weekly number of trades over the 25 week period. The sample includes insider trading before news announcements by U.K. listed companies published in the Regulatory News Service (RNS) between January 1999 and December 2002. 